\title{
FINANCIAL CRISIS, IMF, AND BANK EFFICIENCY: EMPIRICAL EVIDENCE FROM THE ASEAN-4 BANKING SECTORS
}

\author{
Fadzlan Sufian ${ }^{1}$ \\ Muzafar Shah Habibullah
}

\begin{abstract}
A b s tract
Despite its severity and deep influence on both the real and financial sectors, empirical evidence on the evolution of the performance of the ASEAN-4 banking sectors since the 1997-1998 Asian financial crisis is relatively scarce. By employing the Data Envelopment Analysis (DEA) approach the present study examines for the first time the impact of the Asian financial crisis on the efficiency of the ASEAN-4 countries banking sectors. This study focuses on two major approaches vis. intermediation and revenue approaches. The empirical findings suggest that the estimates of technical efficiency are consistently higher under the revenue approach. We find that banks are relatively inefficient in a more concentrated banking market. However, when we control for countries that participate in IMF program, the concentration ratio exhibits a positive relationship with bank efficiency levels, implying that the more concentrated banking system which participates in IMF program is relatively more efficient in their intermediation function during the post crisis period.
\end{abstract}

Keywords: Bank, Efficiency, DEA, ASEAN.

JEL Classification: G21; G28

1 Fadzlan Sufian is assisten vice president of Khazanah research and investment strategy university putra malaysia (fadzlan.sufian@ Khazanah.com.my) Muzafar Shah is professor and deputy dean i dept. of economics university putra malaysia (muzafar@econ.upm.edu.my) 


\section{PENDAHULUAN}

Biaya ekonomi yang harus ditanggung suatu negara akibat terjadinya banking distress bisa sangat parah. Menurut perkiraan Bank Dunia (2000), biaya fiskal restrukturisasi sektor perbankan untuk memulihkan fungsi sektor ini secara efektif setelah terjadinya krisis perbankan atau banking distress bisa mencapai setengah PDB tahunan suatu negara². Dampak negatif terhadap ekonomi bisa jauh lebih besar daripada perkiraan ini, karena banking distress bisa menyebabkan krisis lain, seperti krisis mata uang, yang bisa makin memperparah ekonomi yang sudah melemah ${ }^{3}$. Disamping itu, pengetatan kredit setelah terjadinya banking distress bisa menyebabkan misalokasi dan kurangnya tingkat pemanfaatan (underutilization) dana, yang bisa menganggu potensi pertumbuhan ekonomi negara yang terkena krisis.

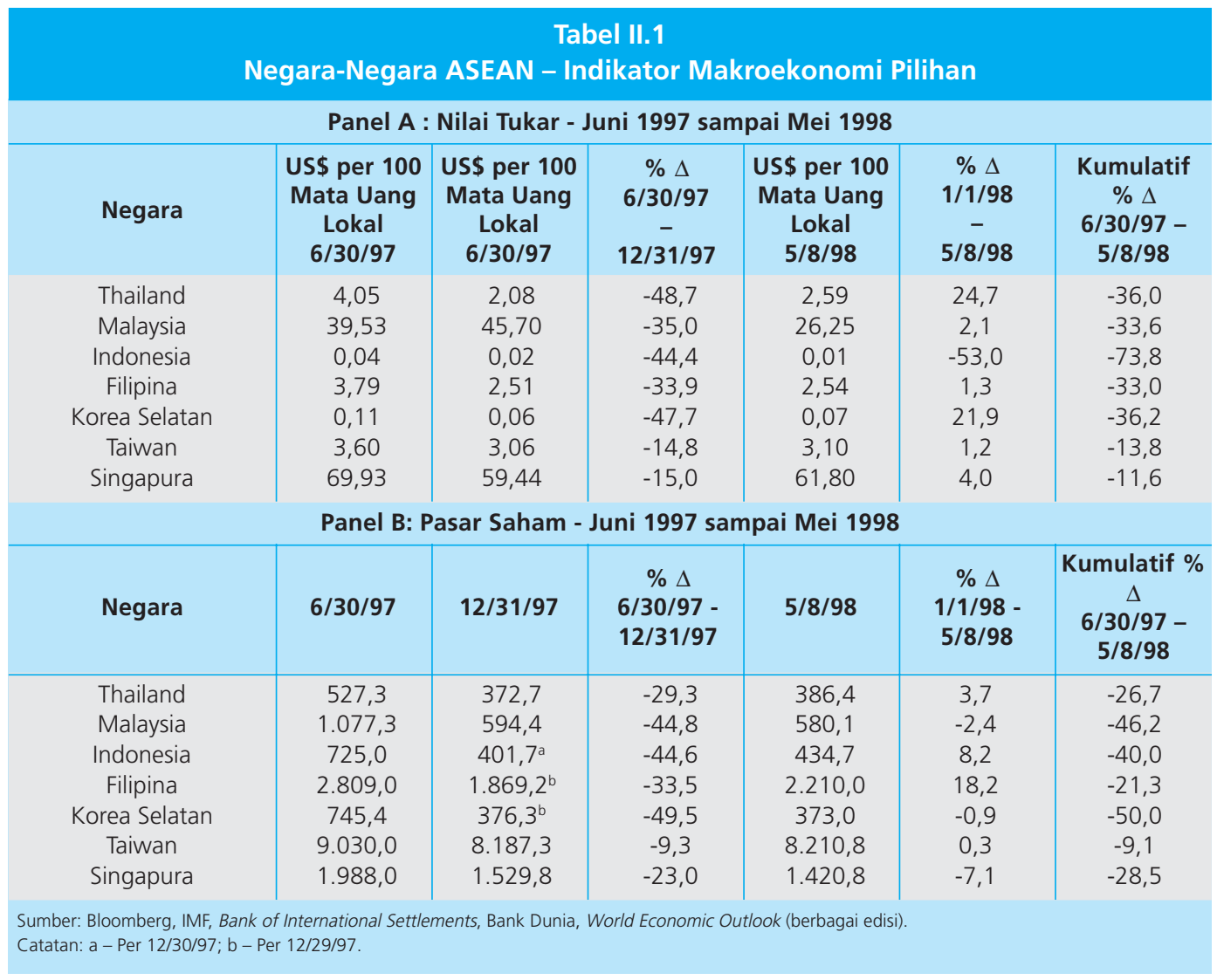

2 Bank Dunia (2000) memperkirakan biaya rekapitalisasi bank di empat negara yang terkenda dampak krisis keuangan Asia bervariasi dari $10 \%$ di Malaysia sampai $58 \%$ di Thailand dari PDB.

3 Dalam literatur, fenomena ini disebut sebagai 'krisis kembar / (twin crisis)'. Pada saat krisis perbankan atau terjadi banking distress, investor bisa mengalokasikan kembali portofolio mereka dari aset domestik ke aset asing. Arus keluar modal dalam jumlah besar akibat re-alokasi modal portofolio bisa menyebabkan berkurangnya jumlah cadangan devisa secara signifikan dan bisa mendorong spekulasi mata uang. 
Tabel II.1

Negara-Negara ASEAN - Indikator Makroekonomi Pilihan (lanjutan)

Panel C: Pertumbuhan PDB Riil

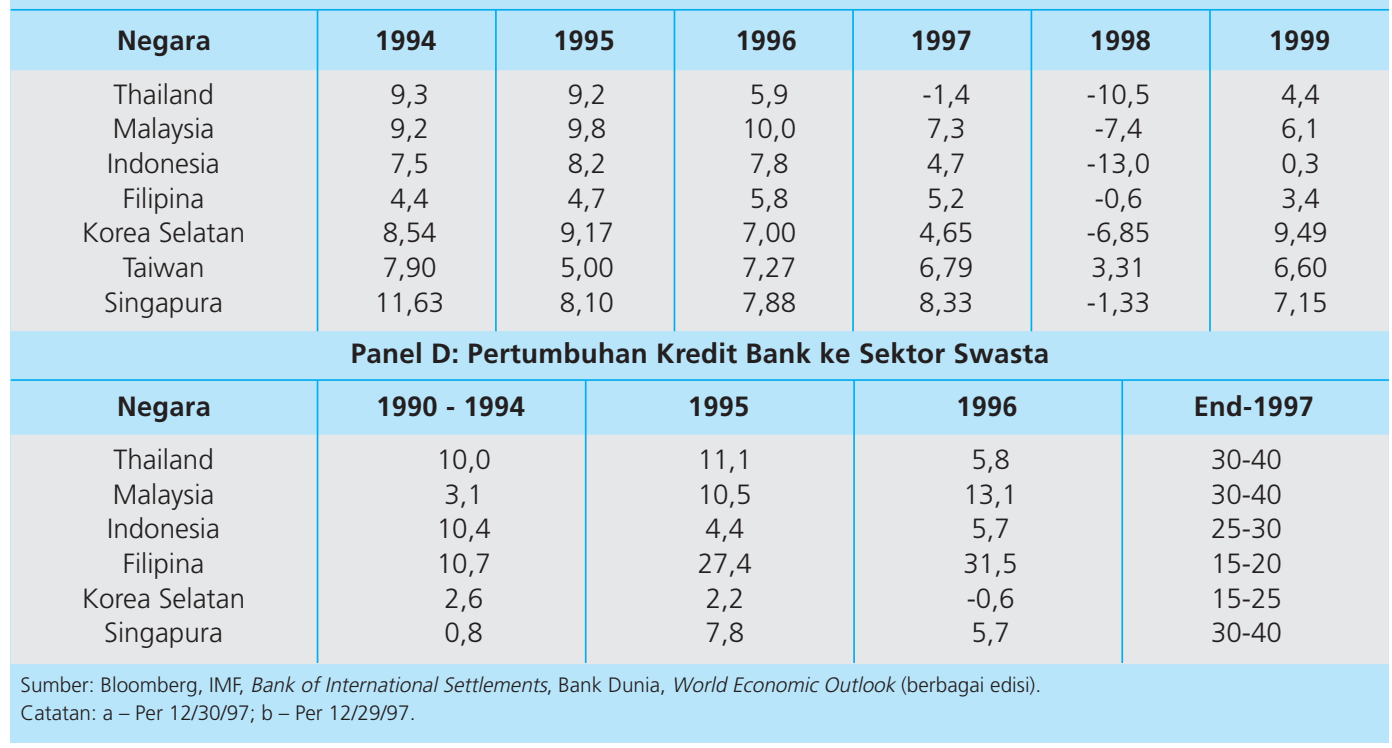

Krisis keuangan Asia, yang menyebar dari Thailand ke negara-negara lain di wilayah itu pada pertengahan kedua tahun 1997, menyebabkan negara-negara yang terkena krisis jatuh ke dalam resesi yang dalam. Pasar mata uang di negara-negara Asia yang tadinya memiliki pertumbuhan tercepat tercatat mengalami kejatuhan besar dari 34\% di Filipina dan 49\% di Thailand, sementara pasar modal juga turun dari 29\% di Thailand sampai 50\% di Korea Selatan pada pertengahan kedua tahun 1997 (Panel A dan B pada Tabel II. 1). Pertumbuhan ekonomi di wilayah itu, yang tercatat mencapai $6 \%$ sampai $8 \%$ sebelum terjadinya krisis, jatuh ke dalam resesi setahun setelah krisis melanda wilayah Asia Timur ${ }^{4}$ (Panel C pada Tabel II. 1).

Kemunculan, penyebaran dan persistensi krisis mendapat banyak perhatian dari ekonom dan analis keuangan di seluruh dunia karena negara-negara yang terkena dampak krisis keuangan Asia disebut-sebut sebagai "macan ekonomi" dan memiliki beberapa kelemahan yang biasanya dikaitkan dengan negara-negara yang meminta bantuan dari IMF. Negara-negara ini memiliki surplus fiskal, bunga simpanan swasta yang tinggi, dan tingkat inflasi yang rendah. Selain itu, pada sebagian besar kasus nilai tukar mata uang negara-negara ini tidak tampak keluar jalur.

4 Frankel dan Rose (1996), Sachs et al. (1996), Kaminsky et al. (1998), Corsetti et al. (1998), Eichengreen dan Rose (1998), Chinn (1998), Kaminsky dan Reinhart (1998), Krugman (1999), dan and Pattillo (1999), mengkaji penyebab krisis keuangan Asia. 
Meskipun memiliki fundamental ekonomi yang sehat, ada beberapa indikator utama yang memperlihatkan masalah serius pada pertengahan tahun 1990an, yang diperparah oleh kelemahan dalam sistem keuangan. Tiap-tiap negara ASEAN-4 (Thailand, Indonesia, Malaysia dan Filipina) mengalami credit boom pada tahun 1990an, yakni pertumbuhan kredit bank dan non-bank kepada sektor swasta yang jauh melebihi pertumbuhan PDB riil (Panel D pada Tabel 1). Credit boom didorong oleh arus masuk modal swasta neto dalam jumlah besar yang diarahkan ke real estate dan ekuitas. Sebagaimana terlihat pada Panel D Tabel 1, exposure ke sektor properti mencapai sekitar 25\% sampai 40\% dari total kredit bank di Thailand, Indonesia, Malaysia dan Singapura ${ }^{5}$. Over extension dan konsentrasi kredit ini menyebabkan negara-negara ASEAN4 rentan terhadap pergeseran siklus kredit. Saat pergeseran ini terjadi, kebutuhan untuk menaikkan suku bunga untuk mengendalikan overheating dan untuk menjaga nilai tukar yang tertatih-tatih menyebabkan turunnya harga-harga properti dan meningkatnya kredit macet (non-performing loan).

Karena tiap negara memiliki struktur ekonomi yang berbeda, maka diambil langkahlangkah ekonomi yang berbeda-beda pula. Sebagai contoh, Thailand dan Indonesia yang mengalami keruntuhan pasar modal, suku bunga yang melonjak tajam, dan depresiasi Bath dan Rupiah, berpaling ke IMF untuk meminta bantuan pembiayaan dan melakukan reshuffle struktural secara masif sebagaimana diminta oleh IMF. Di sisi lain, meskipun Malaysia juga mengalami depresiasi Ringgit dan penurunan pasar saham, namun tindakan penanggulangan krisisnya cukup berbeda dari Thailand dan Indonesia. Malaysia menolak bantuan IMF dan merespon krisis keuangan Asia dengan mengadopsi kebijakan pengendalian modal yang kuat dan rezim nilai tukar tetap (fixed exchange rate) untuk menstabilkan nilai tukar dan mendorong sektor keuangan.

Peran IMF dalam mengatasi krisis keuangan Asia telah mendapat kritik tajam dari banyak pihak. Diantaranya, Radelet dan Sachs (1998) yang berpandangan bahwa beberapa persyaratan yang dikenakan IMF kepada negara-negara yang terkena krisis untuk mendapat bantuan keuangan telah memperparah, dan bukannya mengurangi kepanikan. Mereka berpandangan bahwa negara-negara yang terkena krisis hanyalah korban dari pergeseran sentimen negatif dari para investor internasional. IMF dikritik karena terlalu turut campur dengan membuat rekomendasi detail tentang reformasi sektor keuangan, merekomendasikan nilai tukar yang tinggi, penutupan bank-bank, kebijakan fiskal yang ketat, dan atas dasar argumen bahaya moral.

5 Goldstein dan Hawkins (1998) menemukan bahwa di Thailand, Indonesia, dan Malaysia, exposure ini diperparah oleh rasio kreditagunan yang tinggi ( $80 \%$ sampai $100 \%)$. Selain itu, sebagian besar exposure bank ke pasar properti mencerminkan exposure ke pengembang properti dan bukannya ke pemilik rumah. 
Dalam membahas masalah ini, sejumlah studi telah dilakukan untuk mengkaji dampak program IMF terhadap ekonomi negara-negara yang terkena krisis. Selain analisa tentang hal ini, hampir tidak ada publikasi tentang dampak krisis keuangan Asia terhadap efisiensi sektor perbankan di negara-negara ASEAN-4. Dengan melihat kesenjangan pengetahuan ini, makalah ini bermaksud mengkaji dampak krisis keuangan Asia terhadap efisien sektor perbankan di negara ASEAN-4. Makalah ini juga mencoba membandingkan perbedaan dalam hal efisien sektor perbankan yang ikut serta dalam program IMF dan sektor perbankan yang memutuskan untuk menolak program IMF. Kami membedakan makalah ini dari makalah sebelumnya yang berfokus pada sektor perbankan di negara ASEAN-4 dan menambahkan pengetahuan terkait dengan beberapa hal yang akan dibahas di bawah ini.

Pertama, tidak seperti studi sebelumnya tentang sektor perbankan ASEAN-4, makalah ini bermaksud memberi kontribusi pada literatur yang sudah ada dengan memberikan buktibukti empiris tentang dampak krisis keuangan Asia terhadap efisiensi sektor perbankan ASEAN4. Mengingat bank adalah lembaga keuangan yang dominan di negara-negara ASEAN-4, maka tingkat kesehatan bank sangatlah penting bagi kondisi ekonomi secara umum, sebagaimana terlihat pada saat krisis keuangan Asia, yang menyebabkan banyak lembaga keuangan mengalami distress. Meskipun sudah disepakati bahwa analisa efisiensi dan produktivitas bisa digunakan untuk mengkaji dampak kejadian ekonomi besar seperti krisis ekonomi atau liberalisasi keuangan terhadap kinerja perusahaan perbankan (lihat Fukuyama, 1995; Humphrey dan Pulley, 1997; Leightner dan Lovell, 1998; Isik dan Hassan, 2003), namun dampak krisis keuangan Asia terhadap efisiensi sektor perbankan ASEAN-4 belum dikaji secara kritis.

Kedua, kami membandingkan hasil yang diperoleh dari pendekatan intermediasi yang telah digunakan di sebagian besar studi tentang efisien bank dengan pendekatan pendapatan atau keuntungan yang baru-baru ini diajukan oleh Drake et al. (2006). Ini memungkinkan kami untuk mengamati apakah definisi input dan output yang berbeda akan mempengaruhi skor efisiensi.

Terakhir, kami menggunakan analisa regresi multivariat untuk mengkaji faktor-faktor yang mempengaruhi efisiensi sektor perbankan ASEAN-4 pada periode pasca krisis keuangan Asia. Kami menganalisa bagaimana berbagai karakteristik bank yang berbeda-beda, seperti kapitalisasi, rasio kredit macet, dan ukuran (size), mempengaruhi estimasi efisiensi, mengendalikan variabel struktur pasar dan makroekonomi lain. Kami juga mengkaji apakah negara-negara yang ikut serta dalam program IMF menunjukkan tingkat efisiensi yang lebih tinggi dibandingkan dengan negara-negara yang menolak bantuan IMF.

Makalah ini disusun sebagai berikut. Pada bagian selanjutnya kami akan memaparkan kajian literatur utama. Pada bagian III kami memaparkan pendekatan dalam pengukuran 
perubahan efisiensi serta metode untuk mengestimasi faktor penentu efisiensi bank. Bagian IV membahas hasil, dan akhirnya kami membuat kesimpulan pada bagian $\mathrm{V}$.

\section{TEORI}

Literatur yang mengkaji efisiensi lembaga keuangan dengan teknik parametric dan/atau non-parametric frontier telah sangat berkembang baru-baru ini. Masalah-masalah yang dibahas antara lain dampak risiko pada efisiensi bank (mis. Drake dan Hall, 2003), dampak aktivitas rekening administratif (off-balance sheet) pada efisiensi bank (mis. Lozano-Vivas dan Pasiouras, 2008), hubungan antara efisiensi bank dan harga saham (mis. Pasiouras et al. 2008), dampak merger terhadap efisiensi bank (mis. Al-Sharkas et al. 2008). Perbandingan efisiensi antara bank asing dan domestik juga telah banyak dipelajari (mis. Bhattacharyya et al. 1997; Isik dan Hassan, 2002; Ataullah dan Le, 2006).

Ada banyak literatur dalam setengah abad ini yang membahas tentang efisiensi perbankan di Amerika Serikat (lihat survei di Berger et al. 1993; Berger dan Humphrey, 1997; Berger, 2007 dan referensinya). Akan tetapi, bukti empiris tentang negara-negara Asia masih relatif jarang. Diantara pihak-pihak yang pertama kali menggunakan teknik frontier untuk mengkaji kinerja bank-bank Asia adalah Fukuyama (1993) yang membahas efisiensi 143 bank Jepang pada tahun 1990. Hasilnya memperlihatkan bahwa bank-bank dengan status organisasional yang berbeda memiliki kinerja yang berbeda dalam hal semua langkah efisiensi dan bahwa skala efisiensi memiliki kaitan positif namun lemah dengan ukuran bank.

Studi satu negara yang berfokus pada sektor perbankan Asia Timur biasanya berkonsentrasi pada perbandingan antara kinerja bank asing dan domestik. Umumnya, bukti empiris menunjukkan bahwa bank-bank asing berhasil mendayagunakan kelebihan mereka dan memiliki tingkat efisiensi yang lebih tinggi dibandingkan bank-bank domestik. Leightner dan Lovell (1998) menemukan bahwa rata-rata bank Thailand mengalami penurunan total pertumbuhan produktivitas (total factor productivity growth / TFP), sementara rata-rata bank asing mengalami peningkatan TFP. Unite dan Sullivan (2003) menyatakan bahwa masuknya bank-bank asing ke Filipina telah menyebabkan penurunan spread nilai tukar dan keuntungan bank-bank domestik yang berafilisasi dengan kelompok usaha keluarga. Dalam satu studi tentang sektor perbankan Malaysia, Matthews dan Ismail (2005) menyatakan bahwa bank-bank asing di Malaysia memperlihatkan tingkat efisiensi teknis yang lebih tinggi. Mereka juga menyatakan bahwa produktivitas bank-bank domestik lebih rentan terhadap goncangan makroekonomi dibandingkan dengan bank-bank asing. 
Sektor perbankan Asia Selatan juga telah banyak dipelajari. Sathye (2003) dan Shanmugam dan Das (2004) menemukan bahwa bank-bank milik pemerintah dan asing di India memperlihatkan tingkat efisiensi teknis yang lebih tinggi dibandingkan bank milik swasta. limi (2004) menyatakan bahwa bank-bank yang diprivatisasi di Pakistan adalah bank yang paling efisien, diikuti oleh bank asing dan swasta, sementara bank pemerintah adalah bank yang paling tidak efisien. Hardy dan Patti (2001) menelusuri dampak reformasi keuangan pada profitabilitas, efisiensi biaya dan pendapatan di sektor perbankan Pakistan pada periode tahun 1981-1998. Mereka menunjukkan bahwa liberalisasi keuangan berdampak positif pada kinerja bank. Kemudian, Patti dan Hardy (2005) mengkaji efisiensi biaya dan keuntungan dari bankbank umum Pakistan pada periode 1981-2002. Mereka menemukan bahwa liberalisasi keuangan meningkatkan profitabilitas bank, namun hanya pada tahap pertama dari reformasi keuangan tahun 1991-1992.

Kwan (2003) adalah salah satu dari sedikit studi yang menganalisa efisiensi sektor perbankan Asia Timur dalam lingkungan multi-negara. Dia mempelajari efisiensi kinerja operasional dari bank-bank di tujuh negara Asia pada periode 1992 sampai 1999 dan gagal menemukan adanya hubungan positif antara efisiensi operasional dan tingkat keterbukaan sektor perbankan. Baru-baru ini, Williams dan Nguyen (2005) mengkaji dampak perubahan kepemilikan bank terhadap kinerja sektor perbankan di Indonesia, Malaysia, Thailand, Korea, dan Filipina pada periode 1990-2003. Mereka menyatakan bahwa privatisasi bank meningkatkan kinerja bank tersebut.

\section{METODOLOGI}

\section{1. Data Envelopment Analysis}

Non-parametric Data Envelopment Analysis (DEA) digunakan dengan asumsi variable return to scale (VRS) untuk mengukur efisiensi teknis berorientasi input dari bank-bank di ASEAN4. DEA mencakup membangun non-parametric production frontier berdasarkan pada pengamatan input-output aktual dalam sampel terkait dengan efisiensi mana dari tiap bank dalam sampel yang diukur (Coelli, 1996). Kami akan memberikan penjelasan singkat tentang DEA. Asumsikan ada data pada input $K$ dan output $M$ pada tiap bank $N$. Untuk bank $i$ diwakili oleh vektor $x_{i}$ dan $y_{i} . K \times N$ disebut sebagai input matrix $-X$ dan $M \times N$ sebagai output matrix$Y$. Untuk mengukur efisiensi tiap bank kami menghitung rasio semua input, seperti $\left(u^{\prime} y / v^{\prime} x_{i}\right)$ dimana $u$ adalah $M \times 1$ vektor dari bobot output dan $v$ adalah $K \times 1$ vektor dari bobot input. Untuk memilih bobot optimal kami memaparkan masalah pemprograman matematis sebagai berikut: 
$\min \left(u^{\prime} y_{i} / v^{\prime} x_{i}\right)$,

$u, v$

$u y_{i} / v x_{i} \leq 1, \quad j=1,2, \ldots, N$,

$u, v \geq 0$

Rumus di atas memiliki masalah solusi tak terhingga (infinite solution) dan karenanya kami menggunakan batasan $v^{\prime} x_{i}=1$, yang menjadikannya:

$$
\begin{aligned}
& \min \left(\mu^{\prime} y_{i}\right), \\
& \mu, \varphi \\
& \varphi^{\prime} x_{i}=1 \\
& \mu^{\prime} y_{i}-\varphi^{\prime} x_{j} \leq 0 \quad j=1,2, \ldots, N, \\
& \mu, \varphi \geq 0
\end{aligned}
$$

dimana kami mengganti notasi dari $u$ dan $v$ menjadi $\mu$ dan $\varphi$, untuk mencerminkan transformasi. Dengan menggunakan dualitas pada pemprograman linear, kita bisa menurunkan bentuk yang setara dari masalah ini:

$$
\begin{aligned}
& \min , \theta \\
& \theta, \lambda \\
& y^{\prime}+Y \lambda \geq 0 \\
& \theta x-Y \lambda \geq 0 \\
& \lambda \geq 0
\end{aligned}
$$

dimana adalah scalar yang mewakili nilai skor efisiensi untuk bank $i$ yang bervariasi antara 0 dan 1. $\lambda$ adalah vektor konstanta $N \times 1$. Pemprograman linear harus diselesaikan $N$ kali, sekali untuk masing-masing bank dalam sampel. Untuk menghitung efisiensi dengan asumsi VRS, convexity constraint ( $N 1^{\prime} \lambda=1$ ) akan ditambahkan untuk memastikan bahwa bank yang tidak efisien hanya akan dibandingkan dengan bank-bank yang berukuran sama, dan karenanya menjadi dasar untuk mengukur economies of scale dalam konsep DEA.

\section{III.2 Analisa Regresi Multivariat}

Data Envelopment Analysis, dalam konteks studi tentang pengaruh variabel kontekstual, memiliki kelemahan karena bergantung pada prosedur statistik dua tahap, dimana efisiensi 
yang dihitung pada tahap pertama dimodelkan melalui model regresi pada tahap kedua. Hal ini menimbulkan masalah teknis karena pengukuran efisiensi akan saling terkait. Jika variabel kontekstual bersifat eksogen terhadap proses produksi, Simar dan Wilson (2007), Souza dan Staub (2007) dan Banker dan Natarajan (2008) menunjukkan bahwa analisa dua tahap bisa digunakan dan dalam kondisi kesalahan tertentu, bahkan bisa mendapatkan hasil efisiensi nonparametric stochastic. Banker dan Natarjan (2008) memberikan bukti bahwa penggunaan prosedur dua-tahap yang mencakup DEA diikuti dengan regresi OLS menghasilkan estimator konsisten dari koefisien regresi. Selain itu, McDonald (2009) memberikan landasan statistik bahwa penggunaan DEA dan OLS adalah estimator konsisten, dan jika heteroskedastic consistent standard error dari White (1980) digunakan, maka bisa dilakukan uji sampel dalam jumlah besar yang kuat terhadap heteroskedasticity dan sebaran disturbance.

Didorong oleh hasil-hasil terbaru tentang DEA, dengan mengikuti antara lain Saranga dan Phani (2009), dan Chang et al. (2008), regresi tahap kedua pada studi ini diestimasi dengan menggunakan metode ordinary least square (OLS), dimana standard error dihitung dengan menggunakan uji cross-section White (1980) untuk menyesuaikan cross section heteroskedasticity.

Untuk menguji hubungan antara efisiensi sektor perbankan ASEAN-4 dengan ciri khusus bank, faktor makroekonomi dan faktor spesifik pasar, maka model regresi berikut ini diestimasi:

$$
\theta_{j t}=\beta_{0}+\beta_{1} \Sigma \text { Characteristics }+\beta_{2} \Sigma \text { Econ }+\varepsilon_{j t}
$$

dimana, $\theta_{j t}$ adalah efisiensi teknis dari bank $j$ pada periode $t$ yang didapat dari pendekatan pendapatan dan pendekatan intermediasi DEA, Karakteristik adalah seperangkat karakteristik khusus bank, Econ adalah vektor kondisi ekonomi dan pasar.

Dengan memperluas Persamaan (4) untuk mencerminkan variabel sebagaimana dijabarkan pada Tabel II.3, model dirumuskan sebagai berikut:

$$
\begin{aligned}
& \theta_{j t}=\delta_{t}+\alpha_{j t}\left(E Q A S S_{j t}+L N T A_{j t}+L L P / T L_{j t}+N I E / T A_{j t}+N I I / T A_{j t}+R O A A_{j t}\right) \\
& +\alpha_{i t}\left(L N G D P_{t}+I N F L_{t}+C R \_3+I M F\right)+\varepsilon_{j t}
\end{aligned}
$$

\section{III.3 Spesifikasi Input, Output, dan Data Bank}

Sudah diakui secara umum bahwa pilihan variabel dalam studi efisiensi sangat mempengaruhi hasil. Masalah ini ditambah dengan kenyataan bahwa pemilihan variabel seringkali terhambat oleh tidak adanya data tentang variabel-variabel terkait. Pengukuran biaya dan output dalam perbankan sangat sulit karena banyak layanan keuangan yang dihasilkan dan harga-harga biasanya dikenakan pada banyak layanan keuangan. Peran bank-bank umum 
biasanya adalah mengumpulkan tabungan rumah tangga dan agen-agen lain untuk membiayai kebutuhan investasi perusahaan dan kebutuhan konsumsi perorangan. Ada tiga pendekatan yang mendominasi literatur: pendekatan produksi, pendekatan intermediasi dan baru-baru ini, pendekatan berorientasi pendapatan atau keuntungan. Dua pendekatan pertama menerapkan teori mikroekonomi tradisional perusahaan pada perbankan dan hanya berbeda dalam hal spesifikasi aktivitas perbankan. Pendekatan ketiga melangkah makin maju dan memasukkan beberapa aktivitas khusus perbankan ke dalam teori klasik dan karenanya mengubahnya.

Dalam pendekatan produksi, yang dipelopori oleh Benston (1965), lembaga keuangan didefinisikan sebagai produsen layanan bagi pemegang rekening, yakni, lembaga ini menjalankan transaksi pada rekening tabungan dan memproses dokumen seperti kredit. Menurut pendekatan ini, jumlah rekening atau transaksinya adalah ukuran terbaik untuk output, sementara jumlah pegawai dan modal fisik dianggap sebagai input. Pendekatan ini terutama digunakan dalam mempelajari efisiensi cabang-cabang bank (Berger dan Humphrey, 1992). Di sisi lain, pendekatan intermediasi mengasumsikan bahwa perusahaan keuangan bertindak sebagai perantara (intermediary) antara penabung dan peminjam dan menggunakan total kredit dan sekuritas sebagai output, sedangkan simpanan beserta dengan personil dan modal fisik dianggap sebagai input. Baru-baru ini, Drake et al. (2006) mengajukan pendekatan pendapatan (revenue approach) dalam DEA. Pendekatan pendapatan (atau pendekatan berbasis pemasukan) memandang bank sebagai unit usaha dengan tujuan akhir untuk mendapatkan pemasukan dari total biaya yang dikeluarkan untuk menjalankan usaha. Karenanya, pendekatan ini memandang output bank adalah total pendapatan (pendapatan bunga dan non-bunga) dan input adalah total pengeluaran (pengeluaran bunga dan non-bunga).

Kesesuaian tiap pendekatan bergantung pada kondisi dan situasi. Akan tetapi, berdasarkan pada pertimbangan praktis dan untuk mengkaji ketegaran (robustness) skor efisiensi dalam berbagai alternatif, maka studi ini berfokus pada dua pendekatan utama: pendekatan intermediasi dan pendekatan pendapatan. Dalam pendekatan intermediasi, kami mengasumsikan simpanan (X1), modal (X2) dan pengeluaran non-bunga (X4) sebagai input untuk memproduksi kredit (Y1) dan investasi (Y2). Dalam pendekatan pendapatan, pengeluaran bunga (X5) dan pengeluaran non-bunga (X4) digunakan sebagai input yang memproduksi output seperti pendapatan bunga (Y3) dan pendapatan non-bunga (Y4).

Kami menggunakan data bank dan makroekonomi tahunan dari bank-bank komersial negara-negara ASEAN-4 selama periode 1999-2005. Variabel diperoleh dari informasi neraca yang dipublikasikan dalam laporan tahunan masing-masing bank, sementara data makro didapat dari World Development Indicator (WDI) Bank Dunia. Total sampel mencakup lebih dari 80\% total aset sektor perbankan Malaysia, 90\% dari total aset Thailand, 74\% dari total aset Filipina 


\begin{tabular}{|c|c|c|c|c|c|c|c|c|}
\hline \multicolumn{9}{|c|}{$\begin{array}{c}\text { Tabel II.2 } \\
\text { Statistik Deskriptif untuk Input dan Output }\end{array}$} \\
\hline & $\begin{array}{l}\text { Kredit } \\
\text { (Y1) }\end{array}$ & $\begin{array}{l}\text { Investasi } \\
\quad(\mathrm{Y} 2)\end{array}$ & $\begin{array}{c}\text { Pendapatan } \\
\text { Bunga } \\
\text { (Y3) }\end{array}$ & $\begin{array}{c}\text { Pendapatan } \\
\text { Non-Bunga } \\
\text { (Y4) }\end{array}$ & $\begin{array}{c}\text { Total } \\
\text { Simpanan } \\
\text { (X1) }\end{array}$ & $\begin{array}{l}\text { Modal } \\
(\times 2)\end{array}$ & $\begin{array}{l}\text { Pengeluaran } \\
\text { Bunga } \\
\text { (X3) }\end{array}$ & $\begin{array}{l}\text { Pengeluaran } \\
\text { Non-Bunga } \\
\text { (X4) }\end{array}$ \\
\hline \multicolumn{9}{|c|}{ Panel A : Malaysia } \\
\hline $\begin{array}{l}\text { Min } \\
\text { Mean } \\
\text { Max } \\
\text { S.D }\end{array}$ & $\begin{array}{c}304,7 \\
36.336,2 \\
126.005,2 \\
28.568,9\end{array}$ & $\begin{array}{c}82,4 \\
4.793,8 \\
29.846,6 \\
5.321,0\end{array}$ & $\begin{array}{c}16,2 \\
2.931,9 \\
9.616,5 \\
2.211,2\end{array}$ & $\begin{array}{c}11,7 \\
622,3 \\
2.424,9 \\
521,7\end{array}$ & $\begin{array}{c}82,0 \\
37.596,5 \\
131.068,0 \\
29.328,8\end{array}$ & $\begin{array}{c}0,3 \\
552,3 \\
1.528,1 \\
402,1\end{array}$ & $\begin{array}{c}11,1 \\
1.485,2 \\
6.148,5 \\
1.149,0\end{array}$ & $\begin{array}{c}10,5 \\
873,7 \\
2.938,8 \\
634,8\end{array}$ \\
\hline \multicolumn{9}{|c|}{ Panel B : Thailand } \\
\hline $\begin{array}{l}\text { Min } \\
\text { Mean } \\
\text { Max } \\
\text { S.D }\end{array}$ & $\begin{array}{c}3.482,4 \\
374,592,3 \\
978.372,5 \\
282.301,1\end{array}$ & $\begin{array}{c}4,4 \\
53.087,3 \\
256.903,8 \\
54.578,8\end{array}$ & $\begin{array}{c}1.144,7 \\
21.954,4 \\
67.114,3 \\
17.716,0\end{array}$ & $\begin{array}{c}23,8 \\
5.692,1 \\
21.461,2 \\
5.382,3\end{array}$ & \begin{tabular}{|c|}
$26.069,1$ \\
$432.377,4$ \\
$1.195,366,5$ \\
$334.933,7$
\end{tabular} & $\begin{array}{c}103,1 \\
12.392,7 \\
35.233,7 \\
10.322,5\end{array}$ & $\begin{array}{c}1.172,1 \\
12.244,4 \\
57.771,8 \\
11.021,3\end{array}$ & $\begin{array}{c}404,9 \\
12.337,9 \\
40.623,8 \\
10.123,9\end{array}$ \\
\hline \multicolumn{9}{|c|}{ Panel C : Indonesia } \\
\hline $\begin{array}{l}\text { Min } \\
\text { Mean } \\
\text { Max } \\
\text { S.D }\end{array}$ & $\begin{array}{c}45.172,3 \\
10.778,081,4 \\
106.693,088,0 \\
18.710 .265,5\end{array}$ & $\begin{array}{c}17,8 \\
12.088,763,3 \\
150.770,000,0 \\
25.326 .765,6\end{array}$ & \begin{tabular}{|c|}
$27.708,3$ \\
$3.179,087,0$ \\
$31.474,380,0$ \\
$5.710,159,2$
\end{tabular} & \begin{tabular}{|c|}
270,4 \\
$553.364,6$ \\
$7.690,285,0$ \\
$1.158,807,1$
\end{tabular} & \begin{tabular}{c|}
$13.906,1$ \\
$24.125,755,3$ \\
$206.289,664,0$ \\
$41.960,002,4$
\end{tabular} & \begin{tabular}{|c|}
162,6 \\
$569.425,8$ \\
$5.483 .628,0$ \\
$996.137,5$
\end{tabular} & $\begin{array}{c}10.313,8 \\
2.319 .251,4 \\
35.552 .660,0 \\
4.736 .490,6\end{array}$ & $\begin{array}{c}5.591,6 \\
1.005,351,5 \\
17.351,460,0 \\
2.022 .434,2\end{array}$ \\
\hline \multicolumn{9}{|c|}{ Panel D : Filipina } \\
\hline $\begin{array}{l}\text { Min } \\
\text { Mean } \\
\text { Max } \\
\text { S.D }\end{array}$ & $\begin{array}{c}10,1 \\
52.104,4 \\
270.006,5 \\
67.672,8\end{array}$ & $\begin{array}{c}0,8 \\
21.298,5 \\
141.583,0 \\
28.168,8\end{array}$ & $\begin{array}{c}8,6 \\
7.251,5 \\
38.307,5 \\
9.103,2\end{array}$ & $\begin{array}{c}4,4 \\
2.350,4 \\
11.895,4 \\
2.899,3\end{array}$ & $\begin{array}{c}242,3 \\
83.673,6 \\
424.248,0 \\
105.816,0\end{array}$ & $\begin{array}{c}44,9 \\
6.812,9 \\
42.282,5 \\
10.385,7\end{array}$ & $\begin{array}{c}4,7 \\
4.202,6 \\
25.078,5 \\
5.081,0\end{array}$ & $\begin{array}{c}19,3 \\
3.780,8 \\
18.864,4 \\
4.638,5\end{array}$ \\
\hline $\begin{array}{l}\text { Catatan: Y1 } \\
\text { Pendapatan } \\
\text { jaminan, da } \\
\text { bangunan, } \\
\text { Sumber. Lap }\end{array}$ & $\begin{array}{l}\text { (termasuk kr } \\
\text { unga (diartik } \\
\text { ungan nilai t } \\
\text { alatan), X3: } P \\
\text { hunan Bank }\end{array}$ & $\begin{array}{l}\text { dit kepada nasaba } \\
\text { an sebagai fee inc } \\
\text { ukar), X1: Total Sin } \\
\text { engeluaran Bunga } \\
\text { dan kalkulasi penu }\end{array}$ & $\begin{array}{l}\text { ah dan bank lain), } \\
\text { come dan pendap } \\
\text { mpanan (termasuk } \\
\text { a, X4: Pengeluaran } \\
\text { ulis }\end{array}$ & $\begin{array}{l}\text { Y2: Investasi (mer } \\
\text { oatan non-bunga } \\
\text { k simpanan dari n } \\
\text { n Non-Bunga. }\end{array}$ & $\begin{array}{l}\text { ncakup dealing da } \\
\text { lainnya, yang ant } \\
\text { nasabah dan bank }\end{array}$ & $\begin{array}{l}\text { sekuritas inves } \\
\text { ra lain terdiri } \\
\text { ain), X2: Moda }\end{array}$ & $\begin{array}{l}\text { asi), Y3: Pendapa } \\
\text { as komisi, biaya } \\
\text { (diukur dari nilai }\end{array}$ & $\begin{array}{l}\text { tan Bunga, Y4: } \\
\text { layanan, biaya } \\
\text { i buku properti, }\end{array}$ \\
\hline
\end{tabular}

dan 35\% dari total aset sektor perbankan Indonesia. Tabel II.2 memaparkan ringkasan statistik variabel output dan input yang digunakan untuk membangun model DEA.

Beberapa atribut bank dan industri bisa mempengaruhi tingkat efisiensi bank tertentu. Kami menggunakan berbagai variabel spesifik bank untuk mengendalikan teknologi produksi bank, pangsa pasar produk dan input yang mereka hadapi, dan faktor-faktor lain yang bisa mengacaukan hubungan empiris antara karakteristik dan efisiensi bank. Variabel independen yang digunakan untuk menjelaskan efisiensi bank dikelompokkan dalam dua karakteristik utama. Yang pertama mewakili atribut spesifik bank, sementara yang kedua mencakup kondisi ekonomi dan faktor spesifik pasar pada periode kajian. Variabel spesifik bank yang termasuk dalam regresi adalah, EQASS, LNTA, LLP/TL, NIE/TA, NII/TA, dan ROAA. Untuk mengukur hubungan antara faktor ekonomi dan pasar dengan efisiensi bank digunakan LNGDP, INFL, IMF, dan CR_3. Variabel independen dan hubungan hipotesisnya dengan efisiensi dijelaskan pada Tabel II.3. 


\section{Tabel II.3}

Penjelasan Variabel-Variabel yang Digunakan dalam Model Regresi

\begin{tabular}{|c|c|c|}
\hline Variabel & Penjelasan & $\begin{array}{l}\text { Hubungan Hipotesis } \\
\text { dengan Efisiensi }\end{array}$ \\
\hline $\begin{array}{c}\text { EQASS } \\
\text { LNTA } \\
\text { LLP/TL } \\
\text { NIE/TA } \\
\text { NII/TA } \\
\text { ROAA }\end{array}$ & $\begin{array}{l}\text { Karakteristik Bank } \\
\text { Total book value of shareholders equity over total assets } \\
\text { Natural logarithm of total assets } \\
\text { Loan loss provisions over total loans } \\
\text { Non-interest expense over total assets } \\
\text { Non-interest income over total assets } \\
\text { Return on average assets } \\
\text { Kondisi Ekonomi/Pasar } \\
\text { Natural logarithm of gross domestic products } \\
\text { Tingkat inflasi } \\
\text { Proxy untuk konsentrasi dalam hal asset dari tiga bank terbesar. } \\
\text { Dummy variable dengan nilai } 1 \text { untuk bank-bank di negara yang } \\
\text { meminta bantuan IMF, dan } 0 \text { untuk bank-bank di negara yang tidak } \\
\text { meminta bantuan IMF }\end{array}$ & $\begin{array}{c}+/- \\
+/- \\
- \\
- \\
+ \\
+\end{array}$ \\
\hline
\end{tabular}

\section{HASIL DAN ANALISA}

Pada bagian ini, di bahas perubahan efisiensi teknis (technical efficiency / TE) dari sektor perbankan ASEAN-4, yang diukur dengan metode DEA dan dekomposisinya menjadi komponen pure techical efficiency (PTE) dan scale efficiency. Efisiensi bank pertama-tama dikaji dengan menerapkan metode DEA untuk tiap-tiap tahun yang diteliti. Hasilnya diklasifikasi menjadi dua bagian umum. Kedua, kami menjabarkan estimasi efisiensi teknis dalam dua alternatif pendekatan. Untuk menyokong hasil dalam pendekatan DEA, digunakan kerangka regresi multivariat untuk menghubungan tingkat efisiensi bank dengan seperangkat karateristik bank dan variabel makroekonomi dan faktor pasar lainnya.

\section{IV.1 Efisiensi Sektor Perbankan ASEAN-4}

Ringkasan hasil estimasi efisiensi teknis untuk sektor perbankan Malaysia, Indonesia, Filipina, dan Thailand dalam pendekatan intermediasi dan pendekatan pendapatan dipaparkan pada Tabel 4 dan 5. Rata-rata estimasi efisiensi teknis (M) mewakili rata-rata dari semua nilai optimal yang didapatkan dari model Constant Returns to Scale (CRS) untuk masing-masing bank umum. Hasil empiris memperlihatkan adanya asimetri yang besar antar bank terkait dengan skor efisiensi teknis mereka. Secara khusus, pendekatan yang berbeda dalam mengukur input dan output bank menghasilkan estimasi efisiensi yang berbeda pula. Secara umum, estimasi efisiensi teknis terlihat secara konsisten lebih tinggi dalam pendekatan pendapatan. 


\begin{tabular}{|c|c|c|c|c|c|c|c|c|}
\hline \multicolumn{9}{|c|}{$\begin{array}{c}\text { Tabel II.4 } \\
\text { Rata-Rata Efisiensi Teknis - Pendekatan Intermediasi }\end{array}$} \\
\hline \multirow{2}{*}{ Tahun } & \multirow{2}{*}{ \# Bank } & \multirow{2}{*}{$\begin{array}{c}\text { \# Bank } \\
\text { yang } \\
\text { Efisien }\end{array}$} & \multirow{2}{*}{$\begin{array}{l}\text { Rata-rata } \\
\text { Efisiensi } \\
\text { (M) }\end{array}$} & \multirow{2}{*}{$\begin{array}{c}\text { Standar } \\
\text { Deviasi } \\
(\sigma)\end{array}$} & \multicolumn{2}{|c|}{ Interval } & \multirow{2}{*}{$\begin{array}{l}\text { (\%) Bank } \\
\text { dalam I }\end{array}$} & \multirow{2}{*}{$\begin{array}{c}\text { (\%) Bank } 1 \\
\text { Std. Dev. } \\
\text { Dibawah } \\
\text { Mean }\end{array}$} \\
\hline & & & & & $(I=M-\sigma)$ & $(\mathrm{I}=\mathrm{M}+\sigma)$ & & \\
\hline \multicolumn{9}{|c|}{ Panel A : Malaysia } \\
\hline $\begin{array}{l}1999 \\
2000 \\
2001 \\
2002 \\
2003 \\
2004 \\
2005\end{array}$ & $\begin{array}{l}12 \\
10 \\
9 \\
9 \\
9 \\
9 \\
9\end{array}$ & $\begin{array}{l}1 \\
1 \\
1 \\
2 \\
2 \\
2 \\
4\end{array}$ & $\begin{array}{l}0,507 \\
0,627 \\
0,724 \\
0,823 \\
0,827 \\
0,823 \\
0,895\end{array}$ & $\begin{array}{l}0,171 \\
0,153 \\
0,158 \\
0,130 \\
0,118 \\
0,125 \\
0,122\end{array}$ & $\begin{array}{l}0,336 \\
0,474 \\
0,566 \\
0,693 \\
0,709 \\
0,698 \\
0,773\end{array}$ & $\begin{array}{l}0,678 \\
0,780 \\
0,882 \\
0,953 \\
0,945 \\
0,948 \\
1,017\end{array}$ & $\begin{array}{l}91,67 \\
80,00 \\
55,56 \\
66,67 \\
66,67 \\
66,67 \\
77,78\end{array}$ & $\begin{array}{c}0,00 \\
10,00 \\
22,22 \\
11,11 \\
11,11 \\
11,11 \\
22,22\end{array}$ \\
\hline \multicolumn{9}{|c|}{ Panel B : Thailand } \\
\hline $\begin{array}{l}1999 \\
2000 \\
2001 \\
2002 \\
2003 \\
2004 \\
2005\end{array}$ & $\begin{array}{l}13 \\
13 \\
11 \\
11 \\
11 \\
10 \\
10\end{array}$ & $\begin{array}{l}2 \\
2 \\
1 \\
2 \\
3 \\
2 \\
2\end{array}$ & $\begin{array}{l}0,717 \\
0,701 \\
0,724 \\
0,886 \\
0,876 \\
0,851 \\
0,867\end{array}$ & $\begin{array}{l}0,236 \\
0,215 \\
0,118 \\
0,095 \\
0,115 \\
0,102 \\
0,105\end{array}$ & $\begin{array}{l}0,481 \\
0,486 \\
0,606 \\
0,791 \\
0,761 \\
0,749 \\
0,762\end{array}$ & $\begin{array}{l}0,953 \\
0,916 \\
0,842 \\
0,981 \\
0,991 \\
0,953 \\
0,972\end{array}$ & $\begin{array}{l}76,92 \\
76,92 \\
81,82 \\
63,64 \\
63,64 \\
50,00 \\
40,00\end{array}$ & $\begin{array}{c}7,69 \\
7,69 \\
9,09 \\
18,18 \\
9,09 \\
20,00 \\
30,00\end{array}$ \\
\hline \multicolumn{9}{|c|}{ Panel C : Indonesia } \\
\hline $\begin{array}{l}1999 \\
2000 \\
2001 \\
2002 \\
2003 \\
2004 \\
2005\end{array}$ & $\begin{array}{l}28 \\
26 \\
25 \\
25 \\
28 \\
25 \\
25\end{array}$ & $\begin{array}{l}2 \\
2 \\
1 \\
1 \\
2 \\
4 \\
3\end{array}$ & $\begin{array}{l}0,457 \\
0,545 \\
0,360 \\
0,544 \\
0,586 \\
0,702 \\
0,743\end{array}$ & $\begin{array}{l}0,258 \\
0,256 \\
0,195 \\
0,220 \\
0,236 \\
0,228 \\
0,204\end{array}$ & $\begin{array}{l}0,199 \\
0,289 \\
0,165 \\
0,324 \\
0,350 \\
0,474 \\
0,539\end{array}$ & $\begin{array}{l}0,715 \\
0,801 \\
0,555 \\
0,764 \\
0,822 \\
0,930 \\
0,947\end{array}$ & $\begin{array}{l}71,43 \\
57,69 \\
76,00 \\
68,00 \\
67,86 \\
76,00 \\
68,00\end{array}$ & $\begin{array}{l}14,29 \\
23,08 \\
12,00 \\
16,00 \\
17,86 \\
16,00 \\
16,00\end{array}$ \\
\hline \multicolumn{9}{|c|}{ Panel D : Filipina } \\
\hline $\begin{array}{l}1999 \\
2000 \\
2001 \\
2002 \\
2003 \\
2004 \\
2005\end{array}$ & $\begin{array}{l}20 \\
20 \\
20 \\
18 \\
18 \\
16 \\
16\end{array}$ & $\begin{array}{l}1 \\
2 \\
2 \\
3 \\
3 \\
1 \\
2\end{array}$ & $\begin{array}{l}0,672 \\
0,650 \\
0,768 \\
0,749 \\
0,724 \\
0,609 \\
0,624\end{array}$ & $\begin{array}{l}0,157 \\
0,177 \\
0,173 \\
0,185 \\
0,187 \\
0,181 \\
0,218\end{array}$ & $\begin{array}{l}0,515 \\
0,473 \\
0,595 \\
0,564 \\
0,537 \\
0,428 \\
0,406\end{array}$ & $\begin{array}{l}0,829 \\
0,827 \\
0,941 \\
0,934 \\
0,911 \\
0,790 \\
0,842\end{array}$ & $\begin{array}{l}65,00 \\
75,00 \\
60,00 \\
50,00 \\
55,56 \\
75,00 \\
75,00\end{array}$ & $\begin{array}{l}15,00 \\
10,00 \\
15,00 \\
27,78 \\
22,22 \\
18,75 \\
12,50\end{array}$ \\
\hline
\end{tabular}

Di sisi lain, dalam pendekatan intermediasi, bank dikarakterisasikan dengan tingkat efisiensi teknis yang relatif rendah. Sebagai gambaran, pada tahun 1999, hanya satu bank di Malaysia dan Filipina dan dua bank di Indonesia dan Thailand yang diketahui merupakan bank efisien dalam pendekatan intermediasi dan rata-rata efisiensi teknis bank-bank di Malaysia, Indonesia, Filipina dan Thailand adalah, masing-masing, 50,7\%, 45,7\%, 67,2\%, dan 71,7\%. Di sisi lain, dalam pendekatan pendapatan, jumlah bank yang efisien lebih tinggi. Rata-rata tingkat efisiensi juga lebih tinggi. Dengan kata lain, pada periode 1999-2005, tidak ada perubahan (perceptible 


\begin{tabular}{|c|c|c|c|c|c|c|c|c|}
\hline \multirow{3}{*}{ Tahun } & \multicolumn{7}{|c|}{$\begin{array}{l}\text { Tabel II.5 } \\
\text { aknis - Pen }\end{array}$} & \multirow{3}{*}{$\begin{array}{c}\text { (\%) Bank } 1 \\
\text { Std. Dev. } \\
\text { Dibawah } \\
\text { Mean }\end{array}$} \\
\hline & \multirow{2}{*}{ \# Bank } & \multirow{2}{*}{$\begin{array}{c}\text { \# Bank } \\
\text { yang } \\
\text { Efisien }\end{array}$} & \multirow{2}{*}{$\begin{array}{l}\text { Rata-rata } \\
\text { Efisiensi } \\
\text { (M) }\end{array}$} & \multirow{2}{*}{$\begin{array}{c}\text { Standar } \\
\text { Deviasi } \\
(\sigma)\end{array}$} & \multicolumn{2}{|c|}{ Interval } & \multirow{2}{*}{$\begin{array}{c}\text { (\%) Bank } \\
\text { dalam I }\end{array}$} & \\
\hline & & & & & $(\mathrm{I}=\mathrm{M}-\sigma)$ & $(\mathrm{I}=\mathrm{M}+\sigma)$ & & \\
\hline \multicolumn{9}{|c|}{ Panel A : Malaysia } \\
\hline $\begin{array}{l}1999 \\
2000 \\
2001 \\
2002 \\
2003 \\
2004 \\
2005\end{array}$ & $\begin{array}{c}12 \\
10 \\
9 \\
9 \\
9 \\
9 \\
9\end{array}$ & $\begin{array}{l}2 \\
3 \\
2 \\
4 \\
3 \\
3 \\
3\end{array}$ & $\begin{array}{l}0,745 \\
0,899 \\
0,778 \\
0,944 \\
0,877 \\
0,817 \\
0,874\end{array}$ & $\begin{array}{l}0,141 \\
0,108 \\
0,181 \\
0,089 \\
0,141 \\
0,168 \\
0,125\end{array}$ & $\begin{array}{l}0,604 \\
0,791 \\
0,597 \\
0,855 \\
0,736 \\
0,649 \\
0,749\end{array}$ & $\begin{array}{l}0,886 \\
1,007 \\
0,959 \\
1,033 \\
1,018 \\
0,985 \\
0,999\end{array}$ & $\begin{array}{l}66,67 \\
80,00 \\
55,56 \\
77,78 \\
77,78 \\
55,56 \\
55,56\end{array}$ & $\begin{array}{l}16,67 \\
20,00 \\
22,22 \\
11,11 \\
22,22 \\
11,11 \\
33,33\end{array}$ \\
\hline \multicolumn{9}{|c|}{ Panel B : Thailand } \\
\hline $\begin{array}{l}1999 \\
2000 \\
2001 \\
2002 \\
2003 \\
2004 \\
2005\end{array}$ & $\begin{array}{l}13 \\
13 \\
11 \\
11 \\
11 \\
10 \\
10\end{array}$ & $\begin{array}{l}5 \\
3 \\
2 \\
3 \\
3 \\
4 \\
4\end{array}$ & $\begin{array}{l}0,918 \\
0,902 \\
0,782 \\
0,859 \\
0,823 \\
0,958 \\
0,939\end{array}$ & $\begin{array}{l}0,088 \\
0,098 \\
0,120 \\
0,125 \\
0,129 \\
0,063 \\
0,085\end{array}$ & $\begin{array}{l}0,830 \\
0,804 \\
0,662 \\
0,734 \\
0,694 \\
0,895 \\
0,854\end{array}$ & $\begin{array}{l}1,006 \\
1,000 \\
0,902 \\
0,984 \\
0,952 \\
1,021 \\
1,024\end{array}$ & $\begin{array}{l}92,31 \\
84,62 \\
81,82 \\
54,55 \\
54,55 \\
80,00 \\
90,00\end{array}$ & $\begin{array}{c}15,38 \\
15,38 \\
0,00 \\
18,18 \\
18,18 \\
20,00 \\
10,00\end{array}$ \\
\hline \multicolumn{9}{|c|}{ Panel C: Indonesia } \\
\hline $\begin{array}{l}1999 \\
2000 \\
2001 \\
2002 \\
2003 \\
2004 \\
2005\end{array}$ & $\begin{array}{l}29 \\
27 \\
26 \\
26 \\
29 \\
26 \\
25\end{array}$ & $\begin{array}{l}5 \\
5 \\
4 \\
7 \\
6 \\
6 \\
6\end{array}$ & $\begin{array}{l}0,736 \\
0,788 \\
0,685 \\
0,783 \\
0,787 \\
0,830 \\
0,886\end{array}$ & $\begin{array}{l}0,197 \\
0,150 \\
0,206 \\
0,165 \\
0,165 \\
0,138 \\
0,103\end{array}$ & $\begin{array}{l}0,539 \\
0,638 \\
0,479 \\
0,618 \\
0,622 \\
0,692 \\
0,783\end{array}$ & $\begin{array}{l}0,933 \\
0,938 \\
0,891 \\
0,948 \\
0,952 \\
0,968 \\
0,989\end{array}$ & $\begin{array}{l}62,07 \\
59,26 \\
57,69 \\
57,69 \\
62,07 \\
61,54 \\
64,00\end{array}$ & $\begin{array}{l}17,24 \\
18,52 \\
19,23 \\
15,38 \\
13,79 \\
15,38 \\
12,00\end{array}$ \\
\hline \multicolumn{9}{|c|}{ Panel D : Filipina } \\
\hline $\begin{array}{l}1999 \\
2000 \\
2001 \\
2002 \\
2003 \\
2004 \\
2005\end{array}$ & $\begin{array}{l}20 \\
19 \\
20 \\
18 \\
18 \\
16 \\
14\end{array}$ & $\begin{array}{l}4 \\
5 \\
6 \\
6 \\
3 \\
2 \\
3\end{array}$ & $\begin{array}{l}0,785 \\
0,810 \\
0,872 \\
0,839 \\
0,811 \\
0,798 \\
0,843\end{array}$ & $\begin{array}{l}0,176 \\
0,180 \\
0,171 \\
0,156 \\
0,149 \\
0,136 \\
0,117\end{array}$ & $\begin{array}{l}0,609 \\
0,630 \\
0,701 \\
0,683 \\
0,662 \\
0,662 \\
0,726\end{array}$ & $\begin{array}{l}0,961 \\
0,990 \\
1,043 \\
0,995 \\
0,960 \\
0,934 \\
0,960\end{array}$ & $\begin{array}{l}60,00 \\
52,63 \\
85,00 \\
55,56 \\
72,22 \\
68,75 \\
57,14\end{array}$ & $\begin{array}{l}15,00 \\
21,05 \\
15,00 \\
11,11 \\
11,11 \\
18,75 \\
21,43\end{array}$ \\
\hline
\end{tabular}

change) dalam jumlah bank yang efisien pada kedua pendekatan untuk sektor perbankan ASEAN-4.

Penyebaran skor efisiensi teknis sebagaimana terukur oleh standar deviasi secara kasar menggambarkan tren penurunan sektor perbankan ASEAN-4. Di sisi lain, persentase bank yang memiliki efisiensi teknis dalam interval satu standar deviasi sekitar mean berkisar antara 40\% sampai 92\% di sektor perbankan Malaysia, Indonesia, Filipina, dan Thailand. Angkaangka ini lebih besar jika menggunakan pendekatan pendapatan. Karena estimasi efisiensi 
teknis berbeda-beda menurut waktu, maka proporsi ini tidak selalu menyokong tingkat efisiensi sistem perbankan. Sebagai contoh, dalam pendekatan intermediasi sekitar 92,0\%, 77\%, dan $71 \%$ bank memperlihatkan efisiensi teknis dalam interval satu standar deviasi sekitar mean pada tahun 1999 dibandingkan dengan sekitar 78\%, 40\%, dan 68\% di Malaysia, Thailand dan Indonesia pada tahun 2005. Namun demikian bank-bank relatif lebih efisien pada tahun 2005 dibandingkan pada tahun 1999.

Karena bertentangan dengan bechmark perbandingan yang berubah-ubah, proporsi ini mengkuantifikasi jumlah bank yang mendekati rata-rata sejalan dengan waktu dan karenanya hanya memperlihatkan kurtosis penyebaran efisiensi. Misalnya, dalam kasus sektor perbankan Malaysia, skor efisiensi memperlihatkan penyebaran leptokurtic, yakni skor efisiensi memiliki puncak tinggi dengan variasi kecil, yang mengindikasikan bahwa banyak skor yang ada di tengah-tengah sebaran. Di sisi lain, efisiensi sektor perbankan Filipina nampaknya mengikuti sebaran mesokurtic, yakni skor efisiensi memperlihatkan puncak moderat dengan kurva gradual yang mengindikasikan sejumlah skor dalam kisaran tengah sebaran.

Secara keseluruhan, temuan yang dipaparkan pada Tabel II.4 dan II.5 secara jelas memperlihatkan tingginya tingkat inefisiensi beberapa bank di tiap-tiap negara pada periode sampel. Sebagian besar inefisiensi berasal dari rendahnya tingkat penggunaan (under utilization) sumber daya (penyia-nyiaan input). Terakhir, dengan mempertimbangkan evolusi efisiensi sejalan dengan waktu, tidak muncul pola temporal yang jelas dari pendekatan yang berbeda ini. Akan tetapi, terutama dalam pendekatan intermediasi, ada inefisiensi dalam produksi jasa perbankan dan hal ini nampaknya menjadi faktor penentu penting dari biaya bank. Oleh karenanya, pemeriksaan empiris atas kinerja sektor perbankan ASEAN-4 perlu mempertimbangkan adanya inefisiensi.

Setelah efisiensi teknis diukur dengan menggunakan model VRS, scale efficiency diperoleh dengan membagi efisiensi teknis dengan pure technical efficiency. Estimasinya dipaparkan pada Tabel II.6 - II.9. Pada periode sampel, baik ukuran pure technical efficiency maupun scale efficiency, terutama dalam pendekatan intermediasi, menampakkan perbedaan yang signifikan dan tidak mencapai keuntungan efisiensi dalam sektor perbankan ASEAN-4. Estimasi pure technical efficiency dalam pendekatan intermediasi bervariasi dari rendah yakni 71,1\% pada tahun 1999 ke tinggi yakni 95,3\% pada tahun 2005 dalam kasus Malaysia, 86,7\% di tahun 1999 sampai 95,2\% pada tahun 2001 pada kasus Thailand, 60,2\% di tahun 1999 sampao 80,4\% di tahun 2005 pada kasus Indonesia, dan 77,8\% di tahun 2004 sampai 87,9\% di tahun 2001 pada kasus Filipina. Persentase bank yang memiliki pure technical efficiency dalam interval satu standar deviasi sekitar mean berfluktuasi sekitar 42\% sampai 89\% di Malaysia, 46\% sampai $91 \%$ di Thailand, $48 \%$ sampai $88 \%$ di Indonesia, dan 78\% sampai $85 \%$ di Filipina 


\begin{tabular}{|c|c|c|c|c|c|c|c|c|}
\hline \multicolumn{9}{|c|}{$\begin{array}{c}\text { Tabel II.6 } \\
\text { Rata-Rata Pure Technical Efficiency - Pendekatan Intermediasi }\end{array}$} \\
\hline \multirow{2}{*}{ Tahun } & \multirow{2}{*}{ \# Bank } & \multirow{2}{*}{$\begin{array}{l}\text { \# Bank } \\
\text { yang } \\
\text { Efisien }\end{array}$} & \multirow{2}{*}{$\begin{array}{l}\text { Rata-rata } \\
\text { Efisiensi } \\
\quad \text { (M) }\end{array}$} & \multirow{2}{*}{$\begin{array}{l}\text { Standar } \\
\text { Deviasi } \\
(\sigma)\end{array}$} & \multicolumn{2}{|c|}{ Interval } & \multirow{2}{*}{$\begin{array}{c}\text { (\%) Bank } \\
\text { dalam I }\end{array}$} & \multirow{2}{*}{$\begin{array}{c}\text { (\%) Bank } 1 \\
\text { Std. Dev. } \\
\begin{array}{c}\text { Dibawah } \\
\text { Mean }\end{array}\end{array}$} \\
\hline & & & & & $(I=M-\sigma)$ & $(\mathbf{I}=\mathbf{M}+\sigma)$ & & \\
\hline \multicolumn{9}{|c|}{ Panel A : Malaysia } \\
\hline $\begin{array}{l}1999 \\
2000 \\
2001 \\
2002 \\
2003 \\
2004 \\
2005\end{array}$ & $\begin{array}{c}12 \\
10 \\
9 \\
9 \\
9 \\
9 \\
9\end{array}$ & $\begin{array}{l}4 \\
3 \\
3 \\
4 \\
4 \\
4 \\
6\end{array}$ & $\begin{array}{l}0,711 \\
0,755 \\
0,802 \\
0,899 \\
0,917 \\
0,912 \\
0,953\end{array}$ & $\begin{array}{l}0,239 \\
0,198 \\
0,180 \\
0,122 \\
0,104 \\
0,117 \\
0,081\end{array}$ & $\begin{array}{l}0,472 \\
0,557 \\
0,622 \\
0,777 \\
0,813 \\
0,795 \\
0,872\end{array}$ & $\begin{array}{l}0,950 \\
0,953 \\
0,982 \\
1,021 \\
1,021 \\
1,029 \\
1,034\end{array}$ & $\begin{array}{l}41,67 \\
50,00 \\
44,44 \\
88,89 \\
66,67 \\
77,78 \\
88,89\end{array}$ & $\begin{array}{l}25,00 \\
20,00 \\
22,22 \\
11,11 \\
33,33 \\
22,22 \\
11,11\end{array}$ \\
\hline \multicolumn{9}{|c|}{ Panel B : Thailand } \\
\hline $\begin{array}{l}1999 \\
2000 \\
2001 \\
2002 \\
2003 \\
2004 \\
2005\end{array}$ & $\begin{array}{l}13 \\
13 \\
11 \\
11 \\
11 \\
10 \\
10\end{array}$ & $\begin{array}{l}5 \\
6 \\
5 \\
4 \\
3 \\
3 \\
5\end{array}$ & $\begin{array}{l}0,867 \\
0,921 \\
0,952 \\
0,922 \\
0,886 \\
0,885 \\
0,928\end{array}$ & $\begin{array}{l}0,118 \\
0,083 \\
0,067 \\
0,083 \\
0,109 \\
0,083 \\
0,096\end{array}$ & $\begin{array}{l}0,749 \\
0,838 \\
0,885 \\
0,839 \\
0,777 \\
0,802 \\
0,832\end{array}$ & $\begin{array}{l}0,985 \\
1,004 \\
1,019 \\
1,005 \\
0,995 \\
0,968 \\
1,024\end{array}$ & $\begin{array}{l}46,15 \\
84,62 \\
72,73 \\
90,91 \\
63,64 \\
60,00 \\
80,00\end{array}$ & $\begin{array}{c}15,38 \\
15,38 \\
27,27 \\
9,09 \\
9,09 \\
10,00 \\
20,00\end{array}$ \\
\hline \multicolumn{9}{|c|}{ Panel C : Indonesia } \\
\hline $\begin{array}{l}1999 \\
2000 \\
2001 \\
2002 \\
2003 \\
2004 \\
2005\end{array}$ & $\begin{array}{l}28 \\
26 \\
25 \\
25 \\
28 \\
25 \\
25\end{array}$ & $\begin{array}{c}6 \\
11 \\
6 \\
8 \\
6 \\
7 \\
5\end{array}$ & $\begin{array}{l}0,602 \\
0,780 \\
0,728 \\
0,734 \\
0,680 \\
0,753 \\
0,804\end{array}$ & $\begin{array}{l}0,298 \\
0,286 \\
0,248 \\
0,253 \\
0,251 \\
0,231 \\
0,197\end{array}$ & $\begin{array}{l}0,304 \\
0,494 \\
0,480 \\
0,481 \\
0,429 \\
0,522 \\
0,607\end{array}$ & $\begin{array}{l}0,900 \\
1,066 \\
0,976 \\
0,987 \\
0,931 \\
0,984 \\
1,001\end{array}$ & $\begin{array}{l}57,14 \\
80,77 \\
60,00 \\
48,00 \\
57,14 \\
60,00 \\
88,00\end{array}$ & $\begin{array}{l}21,43 \\
19,23 \\
12,00 \\
20,00 \\
21,43 \\
16,00 \\
12,00\end{array}$ \\
\hline \multicolumn{9}{|c|}{ Panel D : Filipina } \\
\hline $\begin{array}{l}1999 \\
2000 \\
2001 \\
2002 \\
2003 \\
2004 \\
2005\end{array}$ & $\begin{array}{l}20 \\
20 \\
20 \\
18 \\
18 \\
16 \\
16\end{array}$ & $\begin{array}{c}7 \\
9 \\
11 \\
9 \\
8 \\
5 \\
4\end{array}$ & $\begin{array}{l}0,826 \\
0,874 \\
0,879 \\
0,849 \\
0,834 \\
0,778 \\
0,782\end{array}$ & $\begin{array}{l}0,186 \\
0,174 \\
0,176 \\
0,193 \\
0,206 \\
0,247 \\
0,251\end{array}$ & $\begin{array}{l}0,640 \\
0,700 \\
0,703 \\
0,656 \\
0,628 \\
0,531 \\
0,531\end{array}$ & $\begin{array}{l}1,012 \\
1,048 \\
1,055 \\
1,042 \\
1,040 \\
1,025 \\
1,033\end{array}$ & $\begin{array}{l}80,00 \\
80,00 \\
85,00 \\
77,78 \\
77,78 \\
81,25 \\
81,25\end{array}$ & $\begin{array}{l}20,00 \\
20,00 \\
15,00 \\
22,22 \\
22,22 \\
18,75 \\
18,75\end{array}$ \\
\hline
\end{tabular}

dalam pendekatan intermediasi. Di sisi lain, dalam pendekatan pendapatan, angka-angkanya cukup stabil di sektor perbankan ASEAN-4 selama bertahun-tahun.

Dari Tabel II.8 dan II.9 terlihat bahwa jumlah bank yang efisien dalam CRS (efisiensi teknis) dan VRS (pure technical efficiency) sangat berbeda, tanpa memandang pilihan berbagai input dan output. Ini jelas memperlihatkan adanya inefisiensi diantara sektor perbankan ASEAN-4. Dalam pendekatan intermediasi, misalnya, Tabel II.8 memperlihatkan bahwa 20\% sampai 60\% bank adalah bank efisien dalam VRS, sementara hanya 10\% sampai $20 \%$ yang efisien dalam 


\begin{tabular}{|c|c|c|c|c|c|c|c|c|}
\hline \multicolumn{9}{|c|}{ Tabel II.7 } \\
\hline \multirow{2}{*}{ Tahun } & \multirow{2}{*}{ \# Bank } & \multirow{2}{*}{$\begin{array}{c}\text { \# Bank } \\
\text { yang } \\
\text { Efisien }\end{array}$} & \multirow{2}{*}{$\begin{array}{l}\text { Rata-rata } \\
\text { Efisiensi } \\
\text { (M) }\end{array}$} & \multirow{2}{*}{$\begin{array}{c}\text { Standar } \\
\text { Deviasi } \\
(\sigma)\end{array}$} & \multicolumn{2}{|c|}{ Interval } & \multirow{2}{*}{$\begin{array}{c}\text { (\%) Bank } \\
\text { dalam I }\end{array}$} & \multirow{2}{*}{$\begin{array}{c}\text { (\%) Bank } 1 \\
\text { Std. Dev. } \\
\text { Dibawah } \\
\text { Mean }\end{array}$} \\
\hline & & & & & $(\mathbf{I}=\mathbf{M}-\sigma)$ & $(\mathrm{I}=\mathbf{M}+\sigma)$ & & \\
\hline \multicolumn{9}{|c|}{ Panel A : Malaysia } \\
\hline $\begin{array}{l}1999 \\
2000 \\
2001 \\
2002 \\
2003 \\
2004 \\
2005\end{array}$ & $\begin{array}{c}12 \\
10 \\
9 \\
9 \\
9 \\
9 \\
9\end{array}$ & $\begin{array}{l}6 \\
5 \\
5 \\
5 \\
6 \\
5 \\
6\end{array}$ & $\begin{array}{l}0,901 \\
0,929 \\
0,912 \\
0,959 \\
0,922 \\
0,889 \\
0,925\end{array}$ & $\begin{array}{l}0,133 \\
0,090 \\
0,106 \\
0,063 \\
0,122 \\
0,163 \\
0,117\end{array}$ & $\begin{array}{l}0,768 \\
0,839 \\
0,806 \\
0,896 \\
0,800 \\
0,726 \\
0,808\end{array}$ & $\begin{array}{l}1,034 \\
1,019 \\
1,018 \\
1,022 \\
1,044 \\
1,052 \\
1,042\end{array}$ & $\begin{array}{l}83,33 \\
80,00 \\
77,78 \\
77,78 \\
77,78 \\
77,78 \\
77,78\end{array}$ & $\begin{array}{l}16,67 \\
20,00 \\
22,22 \\
11,11 \\
22,22 \\
11,11 \\
33,33\end{array}$ \\
\hline \multicolumn{9}{|c|}{ Panel B : Thailand } \\
\hline $\begin{array}{l}1999 \\
2000 \\
2001 \\
2002 \\
2003 \\
2004 \\
2005\end{array}$ & $\begin{array}{l}13 \\
13 \\
11 \\
11 \\
11 \\
10 \\
10\end{array}$ & $\begin{array}{l}7 \\
7 \\
3 \\
5 \\
6 \\
8 \\
7\end{array}$ & $\begin{array}{l}0,964 \\
0,935 \\
0,840 \\
0,900 \\
0,905 \\
0,996 \\
0,952\end{array}$ & $\begin{array}{l}0,051 \\
0,094 \\
0,128 \\
0,114 \\
0,124 \\
0,010 \\
0,087\end{array}$ & $\begin{array}{l}0,913 \\
0,841 \\
0,712 \\
0,786 \\
0,781 \\
0,986 \\
0,865\end{array}$ & $\begin{array}{l}1,015 \\
1,029 \\
0,968 \\
1,014 \\
1,029 \\
1,006 \\
1,039\end{array}$ & $\begin{array}{l}76,92 \\
84,62 \\
72,73 \\
81,82 \\
72,73 \\
90,00 \\
90,00\end{array}$ & $\begin{array}{c}23,08 \\
15,38 \\
0,00 \\
18,18 \\
27,27 \\
10,00 \\
10,00\end{array}$ \\
\hline \multicolumn{9}{|c|}{ Panel C : Indonesia } \\
\hline $\begin{array}{l}1999 \\
2000 \\
2001 \\
2002 \\
2003 \\
2004 \\
2005\end{array}$ & $\begin{array}{l}29 \\
27 \\
26 \\
26 \\
29 \\
26 \\
25\end{array}$ & $\begin{array}{l}16 \\
16 \\
10 \\
13 \\
13 \\
12 \\
11\end{array}$ & $\begin{array}{l}0,876 \\
0,910 \\
0,826 \\
0,885 \\
0,871 \\
0,900 \\
0,920\end{array}$ & $\begin{array}{l}0,170 \\
0,127 \\
0,187 \\
0,160 \\
0,153 \\
0,132 \\
0,095\end{array}$ & $\begin{array}{l}0,706 \\
0,783 \\
0,639 \\
0,725 \\
0,718 \\
0,768 \\
0,825\end{array}$ & $\begin{array}{l}1,046 \\
1,037 \\
1,013 \\
1,045 \\
1,024 \\
1,032 \\
1,015\end{array}$ & $\begin{array}{l}89,66 \\
81,48 \\
76,92 \\
84,62 \\
86,21 \\
76,92 \\
88,00\end{array}$ & $\begin{array}{l}10,34 \\
18,52 \\
23,08 \\
15,38 \\
13,79 \\
23,08 \\
12,00\end{array}$ \\
\hline \multicolumn{9}{|c|}{ Panel D : Filipina } \\
\hline $\begin{array}{l}1999 \\
2000 \\
2001 \\
2002 \\
2003 \\
2004 \\
2005\end{array}$ & $\begin{array}{l}20 \\
19 \\
20 \\
18 \\
18 \\
16 \\
14\end{array}$ & $\begin{array}{l}5 \\
8 \\
7 \\
7 \\
6 \\
5 \\
4\end{array}$ & $\begin{array}{l}0,813 \\
0,865 \\
0,905 \\
0,873 \\
0,866 \\
0,836 \\
0,871\end{array}$ & $\begin{array}{l}0,165 \\
0,167 \\
0,152 \\
0,157 \\
0,168 \\
0,150 \\
0,118\end{array}$ & $\begin{array}{l}0,648 \\
0,698 \\
0,753 \\
0,716 \\
0,698 \\
0,686 \\
0,753\end{array}$ & $\begin{array}{l}0,978 \\
1,032 \\
1,057 \\
1,030 \\
1,034 \\
0,986 \\
0,989\end{array}$ & $\begin{array}{l}60,00 \\
78,95 \\
75,00 \\
77,78 \\
88,89 \\
50,00 \\
50,00\end{array}$ & $\begin{array}{l}15,00 \\
21,05 \\
25,00 \\
22,22 \\
11,11 \\
18,75 \\
21,43\end{array}$ \\
\hline
\end{tabular}

CRS di sektor perbankan ASEAN-4 pada periode penelitian. Ini memperlihatkan bahwa 80\% sampai 90\% bank gagal mencapai ambang CRS karena scale inefficiencies. Karenanya, scale inefficiency nampaknya menjadi masalah serius di sektor perbankan ASEAN-4. Secara umum, rata-rata estimasi scale efficiency di sektor perbankan ASEAN-4 adalah rendah untuk sebagian besar tahun dalam pendekatan intermediasi (Tabel II.8). Dengan demikian, terkait dengan skala operasi saat ini, bank-bank di negara-negara ASEAN-4 cenderung kehilangan output dalam jumlah besar. 


\begin{tabular}{|c|c|c|c|c|c|c|c|c|}
\hline \multicolumn{9}{|c|}{ Tabel II.8 } \\
\hline \multirow{2}{*}{ Tahun } & \multirow{2}{*}{ \# Bank } & \multirow{2}{*}{$\begin{array}{c}\text { \# Bank } \\
\text { yang } \\
\text { Efisien }\end{array}$} & \multirow{2}{*}{$\begin{array}{l}\text { Rata-rata } \\
\text { Efisiensi } \\
\text { (M) }\end{array}$} & \multirow{2}{*}{$\begin{array}{c}\text { Standar } \\
\text { Deviasi } \\
(\sigma)\end{array}$} & \multicolumn{2}{|c|}{ Interval } & \multirow{2}{*}{$\begin{array}{c}\text { (\%) Bank } \\
\text { dalam I }\end{array}$} & \multirow{2}{*}{$\begin{array}{c}\text { (\%) Bank } 1 \\
\text { Std. Dev. } \\
\text { Dibawah } \\
\text { Mean }\end{array}$} \\
\hline & & & & & $(I=M-\sigma)$ & $(\mathbf{I}=\mathbf{M}+\sigma)$ & & \\
\hline \multicolumn{9}{|c|}{ Panel A : Malaysia } \\
\hline $\begin{array}{l}1999 \\
2000 \\
2001 \\
2002 \\
2003 \\
2004 \\
2005\end{array}$ & $\begin{array}{c}12 \\
10 \\
9 \\
9 \\
9 \\
9 \\
9\end{array}$ & $\begin{array}{l}1 \\
1 \\
1 \\
2 \\
2 \\
2 \\
4\end{array}$ & $\begin{array}{l}0,748 \\
0,847 \\
0,909 \\
0,918 \\
0,903 \\
0,906 \\
0,939\end{array}$ & $\begin{array}{l}0,184 \\
0,134 \\
0,075 \\
0,085 \\
0,088 \\
0,096 \\
0,100\end{array}$ & $\begin{array}{l}0,564 \\
0,713 \\
0,834 \\
0,833 \\
0,815 \\
0,810 \\
0,839\end{array}$ & $\begin{array}{l}0,932 \\
0,981 \\
0,984 \\
1,003 \\
0,991 \\
1,002 \\
1,039\end{array}$ & $\begin{array}{l}66,67 \\
50,00 \\
66,67 \\
77,78 \\
55,56 \\
88,89 \\
88,89\end{array}$ & $\begin{array}{l}16,67 \\
30,00 \\
11,11 \\
22,22 \\
22,22 \\
11,11 \\
11,11\end{array}$ \\
\hline \multicolumn{9}{|c|}{ Panel B : Thailand } \\
\hline $\begin{array}{l}1999 \\
2000 \\
2001 \\
2002 \\
2003 \\
2004 \\
2005\end{array}$ & $\begin{array}{l}13 \\
13 \\
11 \\
11 \\
11 \\
10 \\
10\end{array}$ & $\begin{array}{l}2 \\
2 \\
1 \\
2 \\
3 \\
2 \\
2\end{array}$ & $\begin{array}{l}0,836 \\
0,767 \\
0,761 \\
0,960 \\
0,988 \\
0,960 \\
0,936\end{array}$ & $\begin{array}{l}0,245 \\
0,229 \\
0,106 \\
0,029 \\
0,011 \\
0,041 \\
0,082\end{array}$ & $\begin{array}{l}0,591 \\
0,538 \\
0,655 \\
0,931 \\
0,977 \\
0,919 \\
0,854\end{array}$ & $\begin{array}{l}1,081 \\
0,996 \\
0,867 \\
0,989 \\
0,999 \\
1,001 \\
1,018\end{array}$ & $\begin{array}{l}92,31 \\
76,92 \\
81,82 \\
63,64 \\
54,55 \\
90,00 \\
90,00\end{array}$ & $\begin{array}{c}7,69 \\
7,69 \\
9,09 \\
18,18 \\
18,18 \\
10,00 \\
10,00\end{array}$ \\
\hline \multicolumn{9}{|c|}{ Panel C : Indonesia } \\
\hline $\begin{array}{l}1999 \\
2000 \\
2001 \\
2002 \\
2003 \\
2004 \\
2005\end{array}$ & $\begin{array}{l}28 \\
26 \\
25 \\
25 \\
28 \\
25 \\
25\end{array}$ & $\begin{array}{l}2 \\
2 \\
1 \\
1 \\
3 \\
4 \\
4\end{array}$ & $\begin{array}{l}0,766 \\
0,709 \\
0,522 \\
0,745 \\
0,874 \\
0,934 \\
0,926\end{array}$ & $\begin{array}{l}0,177 \\
0,199 \\
0,233 \\
0,158 \\
0,153 \\
0,095 \\
0,107\end{array}$ & $\begin{array}{l}0,589 \\
0,510 \\
0,289 \\
0,587 \\
0,721 \\
0,839 \\
0,819\end{array}$ & $\begin{array}{l}0,943 \\
0,908 \\
0,755 \\
0,903 \\
1,027 \\
1,029 \\
1,033\end{array}$ & $\begin{array}{l}64,29 \\
73,08 \\
64,00 \\
68,00 \\
82,14 \\
92,00 \\
80,00\end{array}$ & $\begin{array}{c}17,86 \\
11,54 \\
8,00 \\
16,00 \\
17,86 \\
8,00 \\
20,00\end{array}$ \\
\hline \multicolumn{9}{|c|}{ Panel D : Filipina } \\
\hline $\begin{array}{l}1999 \\
2000 \\
2001 \\
2002 \\
2003 \\
2004 \\
2005\end{array}$ & $\begin{array}{l}20 \\
20 \\
20 \\
18 \\
18 \\
16 \\
16\end{array}$ & $\begin{array}{l}1 \\
2 \\
3 \\
3 \\
3 \\
1 \\
2\end{array}$ & $\begin{array}{l}0,830 \\
0,753 \\
0,879 \\
0,890 \\
0,883 \\
0,807 \\
0,810\end{array}$ & $\begin{array}{l}0,144 \\
0,161 \\
0,111 \\
0,126 \\
0,139 \\
0,138 \\
0,133\end{array}$ & $\begin{array}{l}0,686 \\
0,592 \\
0,768 \\
0,764 \\
0,744 \\
0,669 \\
0,677\end{array}$ & $\begin{array}{l}0,974 \\
0,914 \\
0,990 \\
1,016 \\
1,022 \\
0,945 \\
0,943\end{array}$ & $\begin{array}{l}55,00 \\
65,00 \\
70,00 \\
77,78 \\
77,78 \\
68,75 \\
50,00\end{array}$ & $\begin{array}{c}20,00 \\
10,00 \\
10,00 \\
22,22 \\
22,22 \\
6,25 \\
25,00\end{array}$ \\
\hline
\end{tabular}




\begin{tabular}{|c|c|c|c|c|c|c|c|c|}
\hline \multicolumn{9}{|c|}{$\begin{array}{c}\text { Table II.9 } \\
\text { Rata-Rata Scale Efficiency - Pendekatan Pendapatan }\end{array}$} \\
\hline \multirow{2}{*}{ Tahun } & \multirow{2}{*}{ \# Bank } & \multirow{2}{*}{$\begin{array}{l}\text { \# Bank } \\
\text { yang } \\
\text { Efisien }\end{array}$} & \multirow{2}{*}{$\begin{array}{l}\text { Rata-rata } \\
\text { Efisiensi } \\
\quad(\mathrm{M})\end{array}$} & \multirow{2}{*}{$\begin{array}{l}\text { Standar } \\
\text { Deviasi } \\
(\sigma)\end{array}$} & \multicolumn{2}{|c|}{ Interval } & \multirow{2}{*}{$\begin{array}{c}\text { (\%) Bank } \\
\text { dalam I }\end{array}$} & \multirow{2}{*}{$\begin{array}{c}\text { (\%) Bank } 1 \\
\text { Std. Dev. } \\
\text { Dibawah } \\
\text { Mean }\end{array}$} \\
\hline & & & & & $(\mathbf{I}=\mathbf{M}-\sigma)$ & $(\mathrm{I}=\mathrm{M}+\sigma)$ & & \\
\hline \multicolumn{9}{|c|}{ Panel A : Malaysia } \\
\hline $\begin{array}{l}1999 \\
2000 \\
2001 \\
2002 \\
2003 \\
2004 \\
2005\end{array}$ & $\begin{array}{c}12 \\
10 \\
9 \\
9 \\
9 \\
9 \\
9\end{array}$ & $\begin{array}{l}2 \\
4 \\
2 \\
4 \\
3 \\
3 \\
3\end{array}$ & $\begin{array}{l}0,837 \\
0,966 \\
0,848 \\
0,982 \\
0,950 \\
0,922 \\
0,948\end{array}$ & $\begin{array}{l}0,153 \\
0,049 \\
0,158 \\
0,032 \\
0,065 \\
0,104 \\
0,090\end{array}$ & $\begin{array}{l}0,684 \\
0,917 \\
0,690 \\
0,950 \\
0,885 \\
0,818 \\
0,858\end{array}$ & $\begin{array}{l}0,990 \\
1,015 \\
1,006 \\
1,014 \\
1,015 \\
1,026 \\
1,038\end{array}$ & $\begin{array}{l}58,33 \\
80,00 \\
77,78 \\
77,78 \\
88,89 \\
88,89 \\
88,89\end{array}$ & $\begin{array}{l}25,00 \\
20,00 \\
22,22 \\
11,11 \\
11,11 \\
11,11 \\
11,11\end{array}$ \\
\hline \multicolumn{9}{|c|}{ Panel B : Thailand } \\
\hline $\begin{array}{l}1999 \\
2000 \\
2001 \\
2002 \\
2003 \\
2004 \\
2005\end{array}$ & $\begin{array}{l}13 \\
13 \\
11 \\
11 \\
11 \\
10 \\
10\end{array}$ & $\begin{array}{l}6 \\
3 \\
2 \\
3 \\
3 \\
5 \\
4\end{array}$ & $\begin{array}{l}0,952 \\
0,966 \\
0,938 \\
0,957 \\
0,913 \\
0,962 \\
0,987\end{array}$ & $\begin{array}{l}0,082 \\
0,057 \\
0,098 \\
0,082 \\
0,105 \\
0,064 \\
0,019\end{array}$ & $\begin{array}{l}0,870 \\
0,909 \\
0,840 \\
0,875 \\
0,808 \\
0,898 \\
0,968\end{array}$ & $\begin{array}{l}1,034 \\
1,023 \\
1,036 \\
1,039 \\
1,018 \\
1,026 \\
1,006\end{array}$ & $\begin{array}{l}84,62 \\
84,62 \\
90,91 \\
81,82 \\
81,82 \\
80,00 \\
90,00\end{array}$ & $\begin{array}{c}15,38 \\
15,38 \\
9,09 \\
18,18 \\
18,18 \\
20,00 \\
10,00\end{array}$ \\
\hline \multicolumn{9}{|c|}{ Panel C : Indonesia } \\
\hline $\begin{array}{l}1999 \\
2000 \\
2001 \\
2002 \\
2003 \\
2004 \\
2005\end{array}$ & $\begin{array}{l}29 \\
27 \\
26 \\
26 \\
29 \\
26 \\
25\end{array}$ & $\begin{array}{l}5 \\
5 \\
4 \\
8 \\
6 \\
6 \\
8\end{array}$ & $\begin{array}{l}0,845 \\
0,870 \\
0,833 \\
0,890 \\
0,904 \\
0,926 \\
0,963\end{array}$ & $\begin{array}{l}0,157 \\
0,125 \\
0,166 \\
0,116 \\
0,094 \\
0,098 \\
0,057\end{array}$ & $\begin{array}{l}0,688 \\
0,745 \\
0,667 \\
0,774 \\
0,810 \\
0,828 \\
0,906\end{array}$ & $\begin{array}{l}1,002 \\
0,995 \\
0,999 \\
1,006 \\
0,998 \\
1,024 \\
1,020\end{array}$ & $\begin{array}{l}82,76 \\
62,96 \\
69,23 \\
76,92 \\
62,07 \\
84,62 \\
84,00\end{array}$ & $\begin{array}{l}17,24 \\
18,52 \\
15,38 \\
23,08 \\
17,24 \\
15,38 \\
16,00\end{array}$ \\
\hline \multicolumn{9}{|c|}{ Panel D : Philippines } \\
\hline $\begin{array}{l}1999 \\
2000 \\
2001 \\
2002 \\
2003 \\
2004 \\
2005\end{array}$ & $\begin{array}{l}20 \\
19 \\
20 \\
18 \\
18 \\
16 \\
14\end{array}$ & $\begin{array}{c}4 \\
6 \\
7 \\
10 \\
3 \\
3 \\
3\end{array}$ & $\begin{array}{l}0,962 \\
0,937 \\
0,960 \\
0,963 \\
0,942 \\
0,957 \\
0,968\end{array}$ & $\begin{array}{l}0,050 \\
0,089 \\
0,067 \\
0,061 \\
0,060 \\
0,047 \\
0,036\end{array}$ & $\begin{array}{l}0,912 \\
0,848 \\
0,893 \\
0,902 \\
0,882 \\
0,910 \\
0,932\end{array}$ & $\begin{array}{l}1,012 \\
1,026 \\
1,027 \\
1,024 \\
1,002 \\
1,004 \\
1,004\end{array}$ & $\begin{array}{l}85,00 \\
73,68 \\
90,00 \\
83,33 \\
66,67 \\
75,00 \\
85,71\end{array}$ & $\begin{array}{l}15,00 \\
26,32 \\
10,00 \\
16,67 \\
33,33 \\
25,00 \\
14,29\end{array}$ \\
\hline
\end{tabular}




\section{IV.2 Faktor Penentu Efisiensi Bank}

Hasil regresi yang berfokus pada hubungan antara efisiensi bank dan variabel penjelas (eksplanatory variable) dipaparkan pada Tabel II.10 dan II.11. Persamaannya didasarkan pada pengamatan terhadap 446 bank (pendekatan intermediasi) dan 451 bank (pendekatan pendapatan) pada periode 1999-2005. Untuk menghemat tempat, hasil keseluruhan regresi, yang mencakup efek acak spesifik waktu, negara dan bank, tidak dipaparkan dalam makalah ini. Pada model regresi 2 sampai 4, kami menambahkan variabel spesifik pasar dan makroekonomi lain dalam spesifikasi dasar (baseline) yang mencakup variabel atribut spesifik bank, hampir seluruh koefisien variabel dasar masih tetap sama: masih memiliki tanda yang sama, urutan magnitude yang sama, masih tetap signifikan sebagaimana dalam regresi baseline (meskipun terkadang pada tingkatan yang berbeda), dan dengan beberapa pengecualian, tidak menjadi signifikan jika tidak dalam regresi baseline. Karenanya, untuk model regresi 2 sampai 4, kami hanya akan membahas hasil dari variabel baru yang ditambahkan ke dalam spesifikasi baseline.

EQASS memperlihatkan hubungan positif pada semua model regresi baik dalam pendekatan intermediasi maupun pendekatan pendapatan. Temuan empiris memperlihatkan bahwa bank yang secara manajerial makin efisien, ceteris paribus, menggunakan lebih sedikit leverage (lebih banyak ekuitas) dibandingkan dengan bank-bank yang kurang efisien. Temuan ini juga mengimplikasikan bahwa makin banyak bank efisien yang terllibat dalam kegiatan yang berisiko dan dalam prosesnya cenderung untuk memiliki lebih banyak ekuitas, baik secara sukarela ataupun secara tidak sukarela, yang alasannya bisa jadi karena usaha bank secara sengaja untuk meningkatkan keamanan (safety cushion).

Koefisien LLP/TL masuk ke dalam semua model regresi pendekatan intermediasi dengan tanda positif, yang sesuai dengan hipotesis penghematan (skimping) dari Berger dan DeYoung (1997). Sebagai ringkasan, Berger dan DeYoung (1997) menyatakan bahwa dalam hipotesis skimping, suatu bank yang memaksimalkan keuntungan jangka panjang bisa secara rasional memilih untuk memiliki biaya yang lebih rendah dalam jangka pendek dengan menghemat (skimping) sumber daya yang digunakan dalam underwriting dan pengawasan kredit, namun menanggung konsekuensi masalah kinerja kredit yang lebih besar. Di sisi lain, dari Tabel II.11 terlihat bahwa LLP/TL menunjukkan hubungan negatif dengan efisiensi bank dalam pendekatan pendapatan.

Dari Tabel II.10 terlihat bahwa NIE/TA berdampak positif dan signifikan terhadap efisiensi bank dalam pendekatan intermediasi dan secara statistik signifikan pada level $1 \%$. Hasil ini menunjukkan bahwa makin banyak bank efisien (dalam hal fungsi intermediasi) yang memiliki perilaku preferensi pengeluaran. Penjelasan yang mungkin atas hal ini adalah bahwa manajemen 
Tabel II.10

Analisa Regresi Multivariat

$$
\begin{gathered}
\text { BANKEFF }_{j t}=\alpha+\beta_{1} \mathrm{EQASS}+\beta_{2} \mathrm{LNTA}+\beta_{3} \mathrm{LLP} / \mathrm{TL}+\beta_{4} \mathrm{NIE} / \mathrm{TA}+\beta_{5} \mathrm{NII} / \mathrm{TA}+\beta_{6} \mathrm{ROAA} \\
+\beta_{7} \mathrm{LNGDP}+\beta_{8} \mathrm{INFL}+\beta_{9} \mathrm{CR} \_3+\beta_{10} \mathrm{IMF}+\varepsilon_{j}
\end{gathered}
$$

Variabel dependennya adalah skor efisiensi teknis bank yang diambil dari pendekatan Intermediasi DEA. EQASS adalah ukuran kapitalisasi bank yang diukur dari total ekuitas pemegang saham dibagi dengan total aset. LNTA adalah besaran (size) bank yang diukur sebagai natural logarithm dari total aset. LLP/TL adalah ukuran risiko yang dihitung sebagai rasio total loan loss provision dibagi dengan total pinjaman, NIE/TA adalah ukuran kualitas manajemen yang dihitung sebagai total pengeluaran non-bunga dibag dengan total aset. NII/TA adalah ukuran proxy untuk diversifikasi pendapatan non-bunga, dihitung sebagai total pendapatan non-bunga dibagi dengan total aset. ROAA adalah ukuran proxyuntuk probabilitas yang diukur sebagai keuntungan sesudah pajak dibagi dengan rata-rata total aset. LNGDP adalah natural logarithm dari produk domestik bruto. INFL adalah tingkat inflasi. CR_3 adalah rasio konsentrasi 3-bank. IMF adalah variabel biner yang memiliki nilai 1 untuk bank-bank di negara-negara yang meminta bantuan IMF, dan 0 untuk bank di negara-negara yang tidak meminta bantuan IMF. Angka dalam tanda kurung adalah standard error.

\begin{tabular}{|c|c|c|c|c|}
\hline & \multicolumn{4}{|c|}{ Pendekatan Intermediasi } \\
\hline & Model 1 & Model 2 & Model 3 & Model 4 \\
\hline KONSTANTA & $\begin{array}{c}0.503437 * * \\
(2.358402)\end{array}$ & $\begin{array}{c}1.580559 * * * \\
(4.672162)\end{array}$ & $\begin{array}{c}0.594610^{* * *} \\
(2.842828)\end{array}$ & $\begin{array}{c}1.695365^{* * *} \\
(5.343458)\end{array}$ \\
\hline EQASS & $\begin{array}{c}0.250131 * * \\
(2.089644)\end{array}$ & $\begin{array}{c}0.287396 * * * \\
(2.729242)\end{array}$ & $\begin{array}{c}0.261460 * * \\
(2.430087)\end{array}$ & $\begin{array}{c}0.300683^{* * *} \\
(3.244123)\end{array}$ \\
\hline LNTA & $\begin{array}{l}0.029413^{*} \\
(1.780343)\end{array}$ & $\begin{array}{c}0.012249 \\
(0.735875)\end{array}$ & $\begin{array}{c}0.024415 \\
(1.517362)\end{array}$ & $\begin{array}{c}0.006847 \\
(0.456302)\end{array}$ \\
\hline LLP/TL & $\begin{array}{l}0.095700 * * \\
(2.172619)\end{array}$ & $\begin{array}{l}0.098050^{* *} \\
(2.359470)\end{array}$ & $\begin{array}{c}0.109337^{* *} \\
(2.152538)\end{array}$ & $\begin{array}{c}0.112911 * * \\
(2.221143)\end{array}$ \\
\hline $\mathrm{NIE} / \mathrm{TA}$ & $\begin{array}{c}1.497771 * * * \\
(3.133859)\end{array}$ & $\begin{array}{c}0.953848 * * * \\
(3.687442)\end{array}$ & $\begin{array}{c}1.552629 * * * \\
(2.962891)\end{array}$ & $\begin{array}{c}1.007398 * * * \\
(3.571843)\end{array}$ \\
\hline $\mathrm{NII/TA}$ & $\begin{array}{c}1.031242 \\
(0.786325)\end{array}$ & $\begin{array}{c}0.790387 \\
(0.746605)\end{array}$ & $\begin{array}{c}1.385434 \\
(1.089119)\end{array}$ & $\begin{array}{c}1.177958 \\
(1.171814)\end{array}$ \\
\hline ROAA & $\begin{array}{c}-0.043997 \\
(-0.148513)\end{array}$ & $\begin{array}{c}-0.247660 \\
(-1.195330)\end{array}$ & $\begin{array}{c}-0.014038 \\
(-0.049738)\end{array}$ & $\begin{array}{c}-0.218282 \\
(-1.137707)\end{array}$ \\
\hline $\begin{array}{l}\text { Kondisi Ekonomi/ } \\
\text { Faktor Pasar }\end{array}$ & & & & \\
\hline LNGDP & $\begin{array}{c}-0.027093 * * * \\
(-3.268134)\end{array}$ & $\begin{array}{c}-0.014913 \\
(-1.206479)\end{array}$ & $\begin{array}{c}-0.039542 * * * \\
(-4.225010)\end{array}$ & $\begin{array}{l}-0.028605^{*} \\
(-1.765998)\end{array}$ \\
\hline INFL & $\begin{array}{c}-0.006849 * * * \\
(-3.058988)\end{array}$ & $\begin{array}{c}0.001548 \\
(0.614152)\end{array}$ & $\begin{array}{c}-0.006453^{* * *} \\
(-3.000705)\end{array}$ & $\begin{array}{c}0.002133 \\
(0.827924)\end{array}$ \\
\hline CR_3 & & $\begin{array}{c}-1.762961^{* * *} \\
(-6.318397)\end{array}$ & & $\begin{array}{c}0.160129 * * * \\
(2.663158)\end{array}$ \\
\hline IMF & & & $\begin{array}{c}0.145644^{* * *} \\
(3.087752)\end{array}$ & $\begin{array}{c}-1.791752^{* * *} \\
(-6.781625)\end{array}$ \\
\hline$R^{2}$ & 0.151956 & 0.215611 & 0.161088 & 0.226527 \\
\hline Adj. $R^{2}$ & 0.136431 & 0.199419 & 0.143771 & 0.208746 \\
\hline $\begin{array}{c}\text { F-statistics } \\
\text { Jumlah Pengamatan }\end{array}$ & $\begin{array}{c}9.787938^{* * *} \\
446\end{array}$ & $\begin{array}{c}13.31627^{* * *} \\
446\end{array}$ & $\begin{array}{c}9.302306^{* * *} \\
446\end{array}$ & $\begin{array}{c}12.73982^{* * *} \\
446\end{array}$ \\
\hline
\end{tabular}

*.. ". dan " mengindikasikan signifikansi pada level 1, 5 dan $10 \%$

yang makin berkualifikasi dan makin profesional mungkin membutuhkan paket remunerasi yang lebih tinggi dan karenanya hubungan positif dengan ukuran efisiensi adalah sesuatu yang wajar (Sathye, 2003). Di sisi lain, dalam pendekatan pendapatan variabel memperlihatkan tanda negatif, yang sesuai dengan hipotesis manajemen yang buruk dari Berger dan DeYoung (1997). Temuan empiris menunjukkan bahwa sektor perbankan ASEAN-4 akan lebih efisien dalam memperoleh pendapatan dengan memiliki manajemen biaya yang efektif. Serupa dengan itu, NII/TA menunjukkan hubungan negatif dengan efisiensi bank dan secara statistik signifikan 


\begin{tabular}{|c|c|c|c|c|}
\hline \multicolumn{5}{|c|}{$\begin{array}{c}\text { Tabel II.11 } \\
\text { Analisa Regresi Multivariat }\end{array}$} \\
\hline \multicolumn{5}{|c|}{ 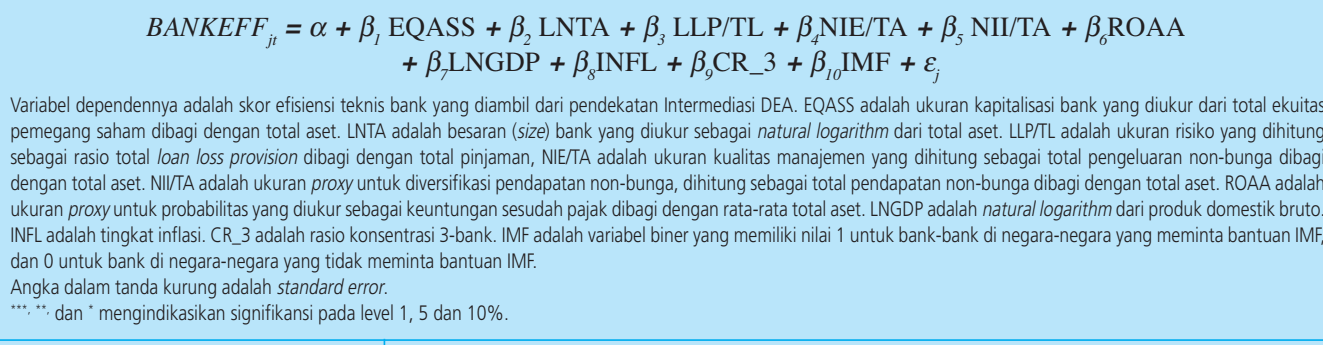 } \\
\hline & \multicolumn{4}{|c|}{ Pendekatan Intermediasi } \\
\hline & Model 1 & Model 2 & Model 3 & Model 4 \\
\hline KONSTANTA & $\begin{array}{l}0.821179 * * * \\
(6.028475)\end{array}$ & $\begin{array}{l}1.443167 * * * \\
(7.606450)\end{array}$ & $\begin{array}{l}0.843351 * * * \\
(5.730668)\end{array}$ & $\begin{array}{l}1.470880 * * * \\
(8.958449)\end{array}$ \\
\hline EQASS & $\begin{array}{l}0.098430 * * \\
(2.079216)\end{array}$ & $\begin{array}{l}0.116046^{* * *} \\
(2.812624)\end{array}$ & $\begin{array}{l}0.103161 * * \\
(2.498129)\end{array}$ & $\begin{array}{l}0.121491 * * * \\
(3.300976)\end{array}$ \\
\hline LNTA & $\begin{array}{c}0.015102 \\
(1.026364)\end{array}$ & $\begin{array}{c}0.006278 \\
(0.529969)\end{array}$ & $\begin{array}{c}0.013988 \\
(0.888992)\end{array}$ & $\begin{array}{c}0.004921 \\
(0.396981)\end{array}$ \\
\hline LLP/TL & $\begin{array}{c}-0.029456^{* *} \\
(-2.201320)\end{array}$ & $\begin{array}{c}-0.028605^{* *} \\
(-2.166050)\end{array}$ & $\begin{array}{l}-0.025272 \\
(-1.450427)\end{array}$ & $\begin{array}{c}-0.023782 \\
(-1.489032)\end{array}$ \\
\hline NIE/TA & $\begin{array}{l}-1.083486^{*} \\
(-1.738295)\end{array}$ & $\begin{array}{c}-1.412780^{* *} \\
(-1.993855)\end{array}$ & $\begin{array}{l}-1.066088^{*} \\
(-1.756050)\end{array}$ & $\begin{array}{c}-1.394950^{* *} \\
(-2.027612)\end{array}$ \\
\hline $\mathrm{NII/TA}$ & $\begin{array}{c}-1.938439 * * \\
(-2.364464)\end{array}$ & $\begin{array}{c}-2.058388^{* *} \\
(-2.533576)\end{array}$ & $\begin{array}{c}-1.827336^{* *} \\
(-2.102631)\end{array}$ & $\begin{array}{c}-1.930232^{* *} \\
(-2.247243)\end{array}$ \\
\hline ROAA & $\begin{array}{l}-0.204223 \\
(-1.546343\end{array}$ & $\begin{array}{c}-0.312806^{* * *} \\
)(-2.709183)\end{array}$ & $\begin{array}{l}-0.198186 \\
(-1.480874)\end{array}$ & $\begin{array}{c}-0.306202^{\star *} \\
(-2.569217)\end{array}$ \\
\hline $\begin{array}{l}\text { Kondisi Ekonomi/ } \\
\text { Faktor Pasar }\end{array}$ & & & & \\
\hline LNGDP & $\begin{array}{c}-0.014512^{* *} \\
(-1.995446)\end{array}$ & $\begin{array}{c}-0.007894 \\
(-1.051472)\end{array}$ & $\begin{array}{c}-0.017976 \text { *** } \\
(-3.926218)\end{array}$ & $\begin{array}{c}-0.011694^{* *} \\
(-2.471931)\end{array}$ \\
\hline INFL & $\begin{array}{l}-0.001858 \\
(-1.497101)\end{array}$ & $\begin{array}{c}0.003071 \\
(1.149538)\end{array}$ & $\begin{array}{l}-0.001706 \\
(-1.493551)\end{array}$ & $\begin{array}{c}0.003266 \\
(1.236520)\end{array}$ \\
\hline CR_3 & & $\begin{array}{l}-1.034231 * * * \\
(-3.386801)\end{array}$ & & $\begin{array}{l}-1.038241 * * * \\
(-3.340021)\end{array}$ \\
\hline IMF & & & $\begin{array}{c}0.038637 \\
(0.543625)\end{array}$ & $\begin{array}{c}0.043094 \\
(0.714016)\end{array}$ \\
\hline R2 & 0.153864 & 0.192086 & 0.155271 & 0.193905 \\
\hline Adj. R2 & 0.138550 & 0.175598 & 0.138031 & 0.175584 \\
\hline $\begin{array}{c}\text { F-statistics } \\
\text { Jumlah Pengamatan }\end{array}$ & $\begin{array}{c}10.04686 * * * \\
451\end{array}$ & $\begin{array}{c}11.65002^{* * *} \\
451\end{array}$ & $\begin{array}{c}9.006755^{* * *} \\
451\end{array}$ & $\begin{array}{c}10.58412^{* * *} \\
451\end{array}$ \\
\hline
\end{tabular}

pada level 5\% dalam pendekatan pendapatan. Hasil empiris ini menunjukkan bahwa bankbank yang memiliki jumlah pendapatan yang tinggi dari sumber-sumber non-bunga relatif tidak efisien terutama pada periode pasca-krisis.

Dari Tabel II.11 terlihat bahwa jika kita mengendalikan rasio konsentrasi 3-bank dalam model regresi pendekatan pendapatan, maka variabel ROAA menunjukkan hubungan positif dengan tingkat efisiensi bank. Hasil ini menunjukkan bahwa bank-bank relatif tidak efisien dalam memperoleh pendapatan dan karenanya menjadi kurang menguntungkan dalam sistem 
perbankan yang lebih terkonsentrasi. LNGDP menunjukkan hubungan negatif pada sebagian besar model regresi baik dalam pendekatan intermediasi maupun pendekatan pendapatan. Serupa dengan itu, INFL masuk ke dalam model regresi pendekatan intermediasi 1 dan 3 dengan tanda negatif.

Ukuran konsentrasi CR_3 memiliki hubungan negatif dengan efisiensi bank baik dalam pendekatan intermediasi maupun pendekatan nilai tambah. Hasil ini menunjukkan bahwa sistem perbankan yang terkonsentrasi cenderung kurang efisien dalam fungsi intermediasinya serta dalam menghasilkan pendapatan. Akan tetapi, saat variabel biner IMF diperkenalkan dalam model regresi pendekatan intermediasi 4, tanda dari koefisien CR_3 berubah menjadi positif. Hasil empiris ini menunjukkan bahwa negara-negara yang ikut serta dalam program IMG memiliki sistem perbankan yang lebih terkonsentrasi. Terakhir, variabel biner IMF memiliki hubungan positif dengan efisiensi bank dalam pendekatan intermediasi. Hasil empiris ini menunjukkan bahwa sistem perbankan dari negara-negara yang berpartisipasi dalam program IMF relatif lebih efisien dalam fungsi intermediasinya. Menarik juga untuk dicatat bahwa setelah mengendalikan konsentrasi sektor perbankan, koefisien variabel IMF menunjukkan tanda negatif. Hasil empiris ini menunjukkan bahwa bank-bank dalam sistem perbankan yang lebih terkonsentrasi yang negaranya berpartisipasi dalam program IMF relatif lebih efisien dalam fungsi intermediasi mereka.

\section{KESIMPULAN}

Meskipun ada pengaruh yang dalam dan parah terhadap sektor riil dan keuangan, namun bukti-bukti empirisnya masih relatif jarang. Studi ini mengkaji evolusi kinerja sektor perbankan negara-negara ASEAN-4 sejak krisis keuangan Asia tahun 1997-1998. Estimasi efisiensi dari masing-masing bank dievaluasi dengan menggunakan pendekatan Data Envelopment Analysis (DEA). Dua pendekatan berbeda, yakni pendekatan intermediasi dan pendekatan pendapatan, digunakan untuk membedakan bagaimana skor efisiensi bervariasi seiring dengan perubahan input dan output. Analisa regresi multivariat juga digunakan untuk mengkaji hubungan antara skor efisien yang berasal dari DEA dengan seperangkat variabel penjelas (explanatory variable), yakni kapitalisasi, ukuran, risiko, profitabilitas, dan struktur pasar.

Estimasi efisiensi teknis terlihat secara konsisten lebih rendah dalam pendekatan intermediasi dibandingkan dalam pendekatan pendapatan. Di sisi lain, dalam pendekatan pendapatan, bank-bank dikarakterisasikan memiliki efisiensi teknis yang relatif lebih tinggi dan jumlah bank yang efisien juga lebih banyak. Penyebaran skor efisiensi memperlihatkan tren penurunan pada sektor perbankan ASEAN-4. Hasil empiris ini menunjukkan bahwa persentase 
bank-bank yang memiliki efisiensi teknis dalam interval satu standar deviasi disekitar mean lebih tinggi pada tahun-tahun sebelumnya. Namun demikian, hasil juga menunjukkan bahwa bank-bank lebih efisien pada tahun-tahun berikutnya, yang bisa dijelaskan dengan kurtosis sebaran efisiensi.

Pada periode penelitian, hasil empiris menunjukkan bahwa jumlah bank yang efisien dalam CRS dan VRS sangat berbeda. Hasil ini mengimplikasikan bahwa scale inefficiency menjadi masalah serius di sektor perbankan ASEAN-4. Bank memiliki rata-rata scale efficiency yang rendah pada sebagian besar tahun, terutama dalam pendekatan intermediasi. Yang bisa dipelajari dari hasil ini adalah bahwa bank-bank di negara-negara ASEAN-4 cenderung kehilangan output dalam jumlah besar terkait dengan skala operasi mereka saat ini.

Hasil dari analisa regresi multivariat menunjukkan bahwa makin banyak bank efisien yang memiliki tingkat ekuitas yang lebih tinggi, yang bisa jadi karena keterlibatan bank-bank ini dalam kegiatan yang lebih berisiko. Hasil empiris menunjukkan bahwa dalam pendekatan intermediasi ukuran proxy untuk risiko berkaitan positif dengan efisiensi bank, dan karenanya mendukung hipotesis penghematan (skimping) dari Berger dan DeYoung (1997). Pada periode penelitian, hasil empiris menunjukkan bahwa bank-bank yang memiliki perilaku preferensi pengeluaran relatif lebih efisien dalam fungsi intermediasi mereka. Di sisi lain, dalam pendekatan pendapatan, hasilnya nampaknya mendukung hipotesis manajemen yang buruk dari Berger dan DeYoung (1997), dimana bank yang lebih efisien adalah bank yang secara efisien mengendalikan biaya operasional. Serupa dengan itu, kami menemukan bahwa bank-bank yang memiliki proporsi pendapatan yang rendah dari sumber-sumber non-bunga relatif efisien dalam pendekatan pendapatan.

Pada periode penelitian, hasil menunjukkan bahwa bank-bank relatif tidak efisien dan karenanya menjadi kurang menguntungkan dalam sistem perbankan yang lebih terkonsentrasi. Rasio konsentrasi yang diukur dengan CR_3 menunjukkan hubungan negatif dengan efisien bank baik dalam pendekatan intermediasi maupun pendekatan pendapatan, yang mengimplikasikan bahwa pasar perbankan yang lebih tidak terkonsentrasi relatif lebih efisien. Akan tetapi, jika kita hanya melihat negara-negara yang berpartisipasi dalam program IMF, rasio konsentrasi menunjukkan hubungan positif dengan tingkat efisiensi bank. Ini menunjukkan bahwa sektor perbankan yang lebih terkonsentrasi yang ikut serta dalam program IMF menjadi relatif lebih efisien dalam fungsi intermediasinya selama periode pasca krisis. 


\section{DAFTAR PUSTAKA}

Al-Sharkas, A., Hassan, M.K. and Lawrence, S. (2008), The Impact of Mergers and Acquisitions on the Efficiency of the U.S. Banking Industry: Further Evidence, Journal of Business, Finance and Accounting 35, 50-70.

Ataullah, A. and Le, H. (2006), Economic Reforms and Bank Efficiency in Developing Countries:

The Case of the Indian Banking Industry, Applied Financial Economics 16, 653-663.

Banker, R.D. and Natarajan, R. (2008), Evaluating Contextual Variables Affecting Productivity Using Data Envelopment Analysis, Operations Research 56 (1), 48-58.

Benston, G.J. (1965), Branch Banking and Economies of Scale, Journal of Finance 20 (2), 312331.

Berg, A., and C. Pattillo, (1999), Predicting Currency Crises: The Indicators and an Alternative, Journal of International Money and Financen18, 561-586.

Berger, A.N. and DeYoung (1997), Problem Loans and Cost Efficiency in Commercial Banks, Journal of Banking and Finance 21 (6), 849-870.

Berger, A.N and Humphrey, D.B. (1992), Measurement and Efficiency Issues in Commercial Banking, in Z.Griliches, (eds.), Measurement Issues in the Service Sectors. National Bureau of Economic Research: University of Chicago Press, 245-279.

Berger, A.N. and Humphrey, D.B. (1997), Efficiency of Financial Institutions: International Survey and Directions for Future Research, European Journal of Operational Research 98, 175-212. Berger, A.N., Hunter, W.C. and Timme, S.G. (1993), The Efficiency of Financial Institutions: A Review and Preview of Research Past, Present and Future, Journal of Banking and Finance 17, 221-249.

Berger A.N. (2007), International Comparisons of Banking Efficiency, Financial Markets, Institutions and Instruments 16, 119-144.

Bhattacharya, A., Lovell, C.A.K. and Sahay, P. (1997) The Impact of Liberalization on the Productive Efficiency of Indian Commercial Banks, European Journal of Operational Research 98, 332345.

Chang, H., Choy, H.L., Cooper, W.W. and Lin, M.W. (2008), The Sarbanes-Oxley Act and the Production Efficiency of Public Accounting Firms in Supplying Accounting Auditing and Consulting Services: An Application of Data Envelopment Analysis, International Journal of Services Sciences 1 (1), 3-20. 
Coelli, T. (1996), A Guide to DEAP Version 2.1: A Data Envelopment Analysis (Computer Program), Working Paper, CEPA, University of New England, Armidale.

Drake, L. and Hall, M.J.B. (2003), Efficiency in Japanese Banking: An Empirical Analysis, Journal of Banking and Finance 27, 891-917.

Drake, L., Hall, M.J.B. and Simper, R. (2006), The Impact of Macroeconomic and Regulatory Factors on Bank Efficiency: A Non-Parametric Analysis of Hong Kong's Banking System, Journal of Banking and Finance 30 (5), 1443-1466.

Fukuyama, H. (1993), Technical and Scale Efficiency of Japanese Commercial Banks: A NonParametric Approach, Applied Economics 25, 1101-1012.

Fukuyama, H. (1995), Measuring Efficiency and Productivity Growth in Japanese Banking: A Non-Parametric Approach, Applied Financial Economics 5 (2), 95-107.

Hardy, D.C. and di Patti, E.B. (2001), Bank Reform and Bank Efficiency in Pakistan, Working Paper, International Monetary Fund. Washington DC: IMF.

Humphrey, D.B. and Pulley, L.B. (1997), Banks' Responses to Deregulation: Profits, Technology, and Efficiency, Journal of Money, Credit and Banking 29, 73-93.

limi, A. (2004), Banking Sector Reforms in Pakistan: Economies of Scale and Scope, and Cost Complementarities, Journal of Asian Economics 15 (3), 507-527.

Isik, I. and Hassan, M.K. (2002), Technical, Scale and Allocative Efficiencies of Turkish Banking Industry, Journal of Banking and Finance 26 (4), 719-766

Isik, I. and Hassan, M.K. (2003), Financial Disruption and Bank Productivity: The 1994 Experience of Turkish Banks, The Quarterly Review of Economics and Finance 43, 291-320.

Kwan, S. H. (2003), Operating Performance of Banks Among Asian Economies: An International and Time Series Comparison, Journal of Banking and Finance 27 (3), 471-489.

Leightner, J.E. and Lovell, C.A.K. (1998), The Impact of Financial Liberalization on the Performance of Thai Banks, Journal of Economics and Business 50, 115-131.

Lozano-Vivas, A. and Pasiouras, F. (2008), The Impact of Non-Traditional Activities on the Estimation of Bank Efficiency: International Evidence, Working Paper, University of Bath.

McDonald, J. (2009), Using Least Squares and Tobit in Second Stage DEA Efficiency Analyses,

European Journal of Operational Research 197, 792-798.

Matthews, K. and Ismail, M. (2005), Efficiency and Productivity Growth of Domestic and Foreign Commercial Banks in Malaysia, Working Paper, Cardiff Business School.

Pasiouras, F., Liadaki, A. and Zopounidis, C. (2008), Bank Efficiency and Share Performance: Evidence from Greece, forthcoming in Applied Financial Economics.

di Patti, E.B. and Hardy, D.C. (2005), Financial Sector Liberalization, Bank Privatization, and Efficiency: Evidence from Pakistan, Journal of Banking and Finance 29 (8-9), 2381-2406. 
Radelet, S. and Sachs, J. (1998), The East Asian Financial Crisis: Diagnosis, Remedies, Prospects, Brookings Papers on Economic Activity 1, 1-74.

Sathye, M. (2003), Efficiency of Banks in a Developing Economy: The Case of India, European Journal of Operational Research 148 (3), 662-671.

Shanmugam, K.R. and Das, A. (2004), Efficiency of Indian Commercial Banks During the Reform Period, Applied Financial Economics 14, 681-686.

Simar, L. and Wilson, P. (2007), Estimation and Inference in Two-Stage, Semi-Parametric Models of Production Process, Journal of Econometrics 136, 31-64.

Souza, G. and Staub, R. (2007), Two-Stage Inference Using Data Envelopment Analysis Efficiency Measurements in Univariate Production Models, Transactions in Operations Research 14, 245-258.

Unite, A.A. and Sullivan, M.J. (2003), The Effect of Foreign Entry and Ownership on the Philippine Domestic Banking Market, Journal of Banking and Finance 27 (12), 2323-2345.

White, H. J. (1980), A Heteroskedasticity-Consistent Covariance Matrix Estimator and a Direct Test for Heteroskedasticity, Econometrica 48, 817-838.

Williams, J. and Nguyen, N. (2005), Financial Liberalisation, Crisis, and Restructuring: A Comparative Study of Bank Performance and Bank Governance in South East Asia, Journal of Banking and Finance 29, 2119-2154.

World Bank (2000), Global Economic Prospects and Developing Countries. 
halaman ini sengaja dikosongkan 